\title{
LEVEL II SCOUR ANALYSIS FOR BRIDGE 36 (RICHVT01050036) on STATE ROUTE 105, crossing STANHOPE BROOK, RICHFORD, VERMONT
}

U.S. Geological Survey Open-File Report 96-584

Prepared in cooperation with

VERMONT AGENCY OF TRANSPORTATION and

FEDERAL HIGHWAY ADMINISTRATION 


\section{LEVEL II SCOUR ANALYSIS FOR BRIDGE 36 (RICHVT01050036) on STATE ROUTE 105, crossing STANHOPE BROOK, RICHFORD, VERMONT}

By Erick M. Boehmler and Michael A. Ivanoff

\section{U.S. Geological Survey Open-File Report 96-584}

Prepared in cooperation with

VERMONT AGENCY OF TRANSPORTATION and

FEDERAL HIGHWAY ADMINISTRATION 


\title{
U.S. DEPARTMENT OF THE INTERIOR BRUCE BABBITT, Secretary
}

\author{
U.S. GEOLOGICAL SURVEY \\ Gordon P. Eaton, Director
}

For additional information write to:

District Chief

U.S. Geological Survey 361 Commerce Way

Pembroke, NH 03275-3718
Copies of this report may be purchased from:

U.S. Geological Survey

Branch of Information Services

Open-File Reports Unit

Box 25286

Denver, CO 80225-0286 


\section{CONTENTS}

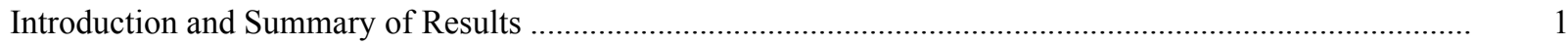

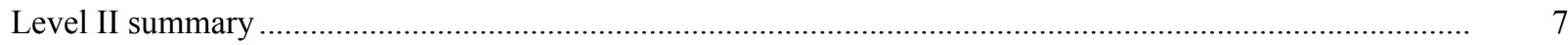

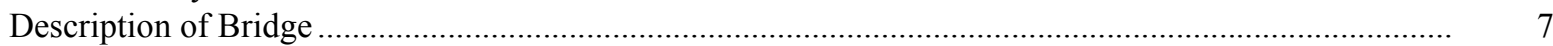

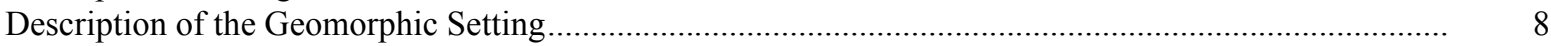

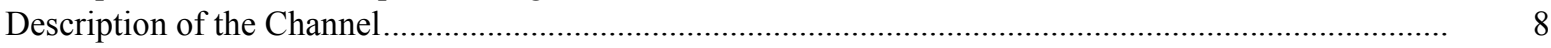

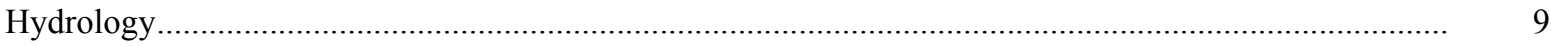

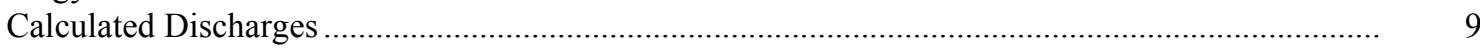

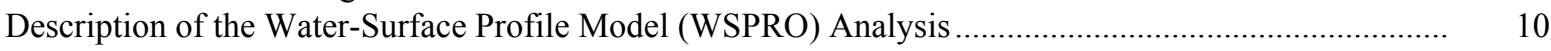

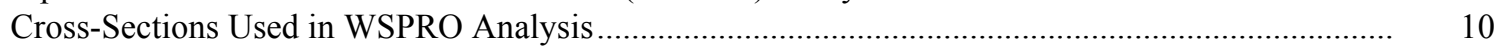

Data and Assumptions Used in WSPRO Model ...................................................................... 11

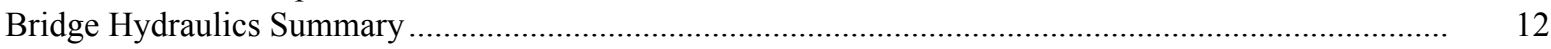

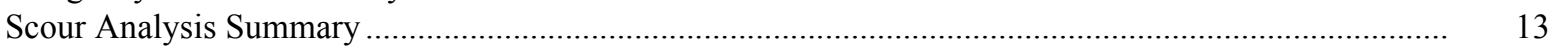

Special Conditions or Assumptions Made in Scour Analysis ...................................................... 13

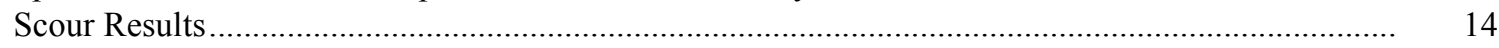

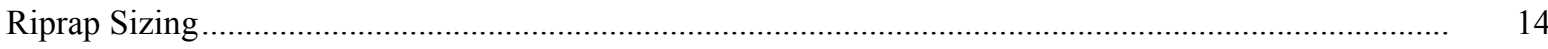

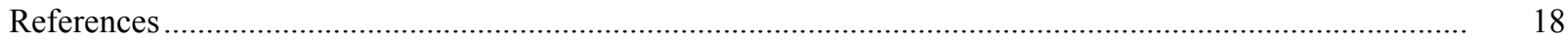

Appendixes:

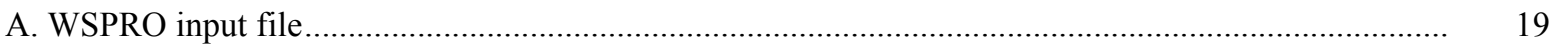

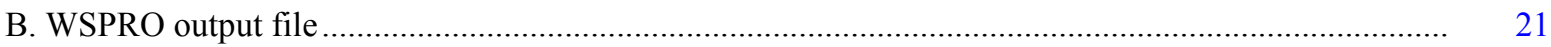

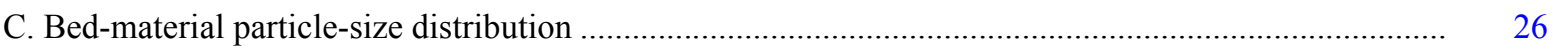

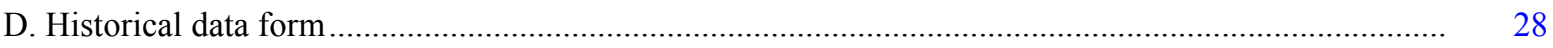

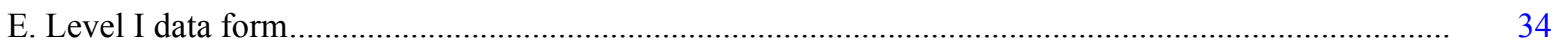

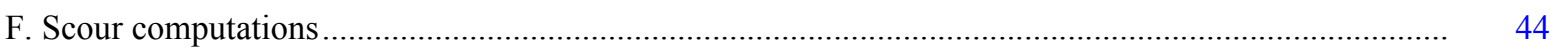

\section{FIGURES}

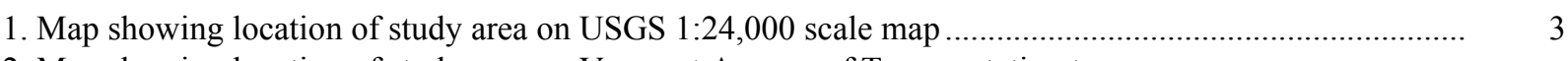

2. Map showing location of study area on Vermont Agency of Transportation town
highway map

3. Structure RICHVT01050036 viewed from upstream (June 28, 1995) ...................................................

4. Downstream channel viewed from structure RICHVT01050036 (June 28, 1995)............................... 5

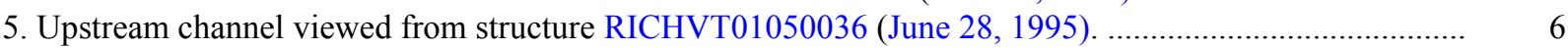

6. Structure RICHVT01050036 viewed from downstream (June 28, 1995)........................................... 6

7. Water-surface profiles for the 100- and 500-year discharges at structure RICHVT01050036 on State Route 105, crossing Stanhope Brook,

Richford, Vermont.....

8. Scour elevations for the 100- and 500-year discharges at structure

RICHVT01050036 on State Route 105, crossing Stanhope Brook,

Richford, Vermont.

3
5
5
6

\section{TABLES}

1. Remaining footing/pile depth at abutments for the 100-year discharge at structure

RICHVT01050036 on State Route 105, crossing Stanhope Brook,

Richford, Vermont

2. Remaining footing/pile depth at abutments for the 500-year discharge at structure

RICHVT01050036 on State Route 105, crossing Stanhope Brook,

Richford, Vermont 


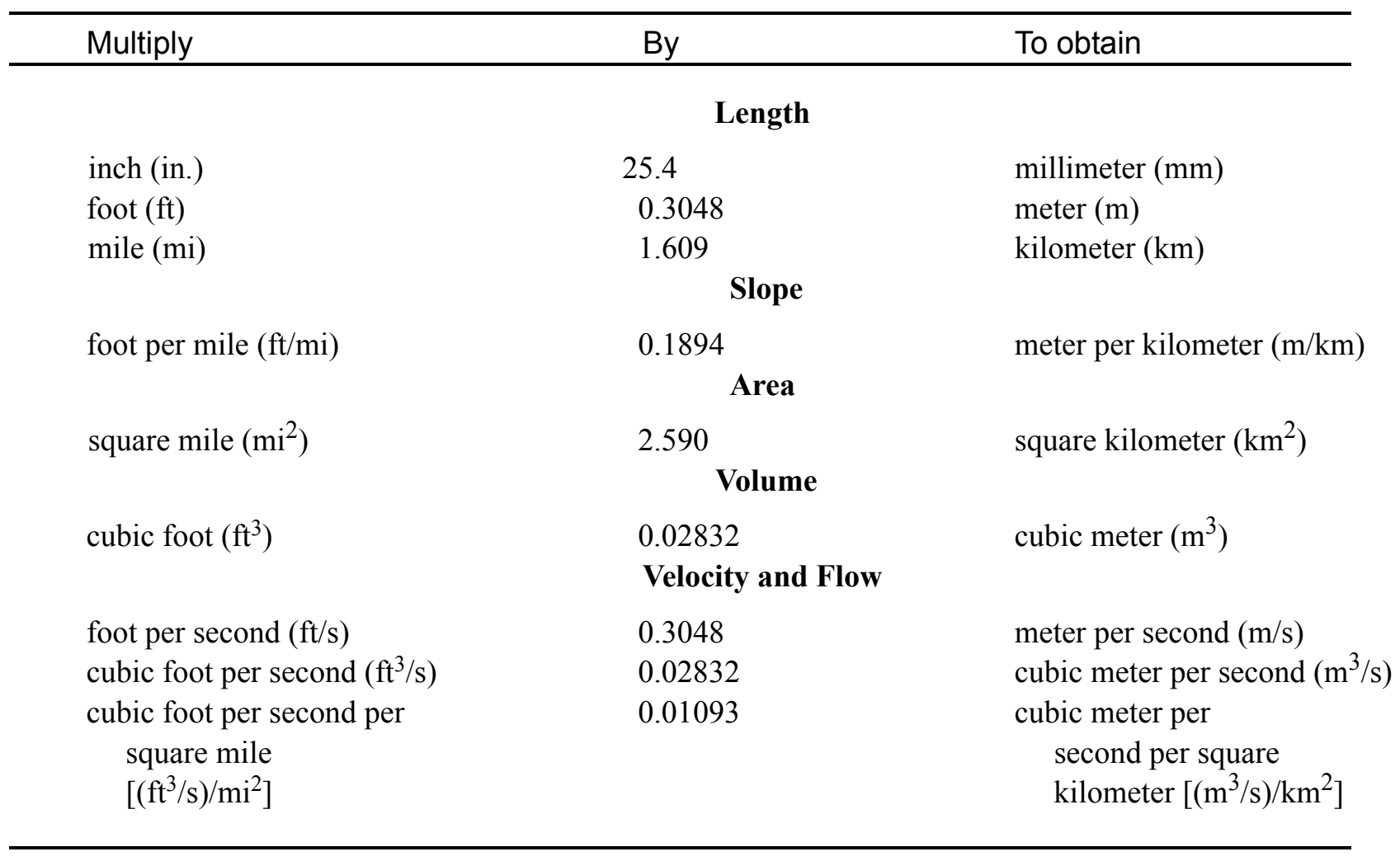

\section{OTHER ABBREVIATIONS}

$\begin{array}{lrlr}\mathrm{BF} & \text { bank full } & \text { LWW } & \text { left wingwall } \\ \mathrm{cfs} & \text { cubic feet per second } & \text { MC } & \text { main channel } \\ \mathrm{D}_{50} & \text { median diameter of bed material } & \text { RAB } & \text { right abutment } \\ \mathrm{DS} & \text { downstream } & \text { RABUT } & \text { face of right abutment } \\ \mathrm{elev} & \text { elevation } & \text { RB } & \text { right bank } \\ \mathrm{f} / \mathrm{p} & \text { flood plain } & \text { ROB } & \text { right overbank } \\ \mathrm{ft}^{2} & \text { square feet } & \text { RWW } & \text { right wingwall } \\ \mathrm{ft} / \mathrm{ft} & \text { feet per foot } & \text { TH } & \text { town highway } \\ \mathrm{JCT} & \text { junction } & \text { UB } & \text { under bridge } \\ \mathrm{LAB} & \text { left abutment } & \text { US } & \text { upstream } \\ \mathrm{LABUT} & \text { face of left abutment } & \text { USGS } & \text { United States Geological Survey } \\ \mathrm{LB} & \text { left bank } & \text { VTAOT Vermont Agency of Transportation } \\ \mathrm{LOB} & \text { left overbank } & \text { WSPRO } & \text { water-surface profile model }\end{array}$

In this report, the words "right" and "left" refer to directions that would be reported by an observer facing downstream. Sea level: In this report, "sea level" refers to the National Geodetic Vertical Datum of 1929-- a geodetic datum derived from a general adjustment of the first-order level nets of the United States and Canada, formerly called Sea Level Datum of 1929.

In the appendices, the above abbreviations may be combined. For example, USLB would represent upstream left bank. 


\title{
LEVEL II SCOUR ANALYSIS FOR BRIDGE 36 (RICHVT01050036) ON STATE ROUTE 105, CROSSING STANHOPE BROOK, RICHFORD, VERMONT
}

\author{
By Erick M. Boehmler and Michael A. Ivanoff
}

\section{INTRODUCTION AND SUMMARY OF RESULTS}

This report provides the results of a detailed Level II analysis of scour potential at structure RICHVT01050036 on State Route 105 crossing Stanhope Brook, Richford, Vermont (figures 1-8). A Level II study is a basic engineering analysis of the site, including a quantitative analysis of stream stability and scour (U.S. Department of Transportation, 1993). Results of a Level I scour investigation also are included in Appendix E of this report. A Level I investigation provides a qualitative geomorphic characterization of the study site. Information on the bridge, gleaned from Vermont Agency of Transportation (VTAOT) files, was compiled prior to conducting Level I and Level II analyses and is found in Appendix D.

The site is in the Green Mountain section of the New England physiographic province in north-central Vermont. The $7.03-\mathrm{mi}^{2}$ drainage area is in a predominantly rural and forested basin. In the vicinity of the study site, the surface cover is short grass except for the upstream left overbank area which is forested.

In the study area, Stanhope Brook has a steep, sinuous channel with a slope of approximately $0.03 \mathrm{ft} / \mathrm{ft}$, an average channel top width of $47 \mathrm{ft}$ and an average channel depth of $5 \mathrm{ft}$. The predominant channel bed material is cobble with a median grain size $\left(\mathrm{D}_{50}\right)$ of $132 \mathrm{~mm}(0.432 \mathrm{ft})$. The geomorphic assessment at the time of the Level I and Level II site visit on June 28, 1995, indicated that the reach was laterally unstable.

The State Route 105 crossing of Stanhope Brook is a 42-ft-long, two-lane bridge consisting of one 38-foot concrete T-beam span (Vermont Agency of Transportation, written communication, March 8, 1995). The bridge is supported by vertical, concrete abutments with wingwalls. The channel is skewed approximately 15 degrees to the opening while the opening-skew-to-roadway is 20 degrees.

A scour hole $0.5 \mathrm{ft}$ deeper than the mean thalweg depth was observed along the downstream end of the right abutment wall during the Level I assessment. The scour protection measures at this site were type- 2 stone fill (less than 36 inches diameter) along the entire lengths of the upstream wingwalls, at the corner of the downstream left abutment and downstream left 
wingwall and the downstream end of the downstream right wingwall. Additional details describing conditions at the site are included in the Level II Summary and Appendices D and E.

Scour depths and rock rip-rap sizes were computed using the general guidelines described in Hydraulic Engineering Circular 18 (Richardson and others, 1995). Total scour at a highway crossing is comprised of three components: 1) long-term streambed degradation; 2) contraction scour (due to accelerated flow caused by a reduction in flow area at a bridge) and; 3) local scour (caused by accelerated flow around piers and abutments). Total scour is the sum of the three components. Equations are available to compute depths for contraction and local scour and a summary of the results of these computations follows.

Contraction scour for all modelled flows ranged from 0.0 to $0.3 \mathrm{ft}$. The worst-case contraction scour occurred at the 500-year discharge. Abutment scour ranged from 6.6 to $9.4 \mathrm{ft}$. The worst-case abutment scour occurred at the 500-year discharge. Additional information on scour depths and depths to armoring are included in the section titled "Scour Results". Scoured-streambed elevations, based on the calculated scour depths, are presented in tables 1 and 2. A cross-section of the scour computed at the bridge is presented in figure 8. Scour depths were calculated assuming an infinite depth of erosive material and a homogeneous particle-size distribution.

It is generally accepted that the Froehlich equation (abutment scour) gives "excessively conservative estimates of scour depths" (Richardson and others, 1995, p. 47). Usually, computed scour depths are evaluated in combination with other information including (but not limited to) historical performance during flood events, the geomorphic stability assessment, existing scour protection measures, and the results of the hydraulic analyses. Therefore, scour depths adopted by VTAOT may differ from the computed values documented herein. 


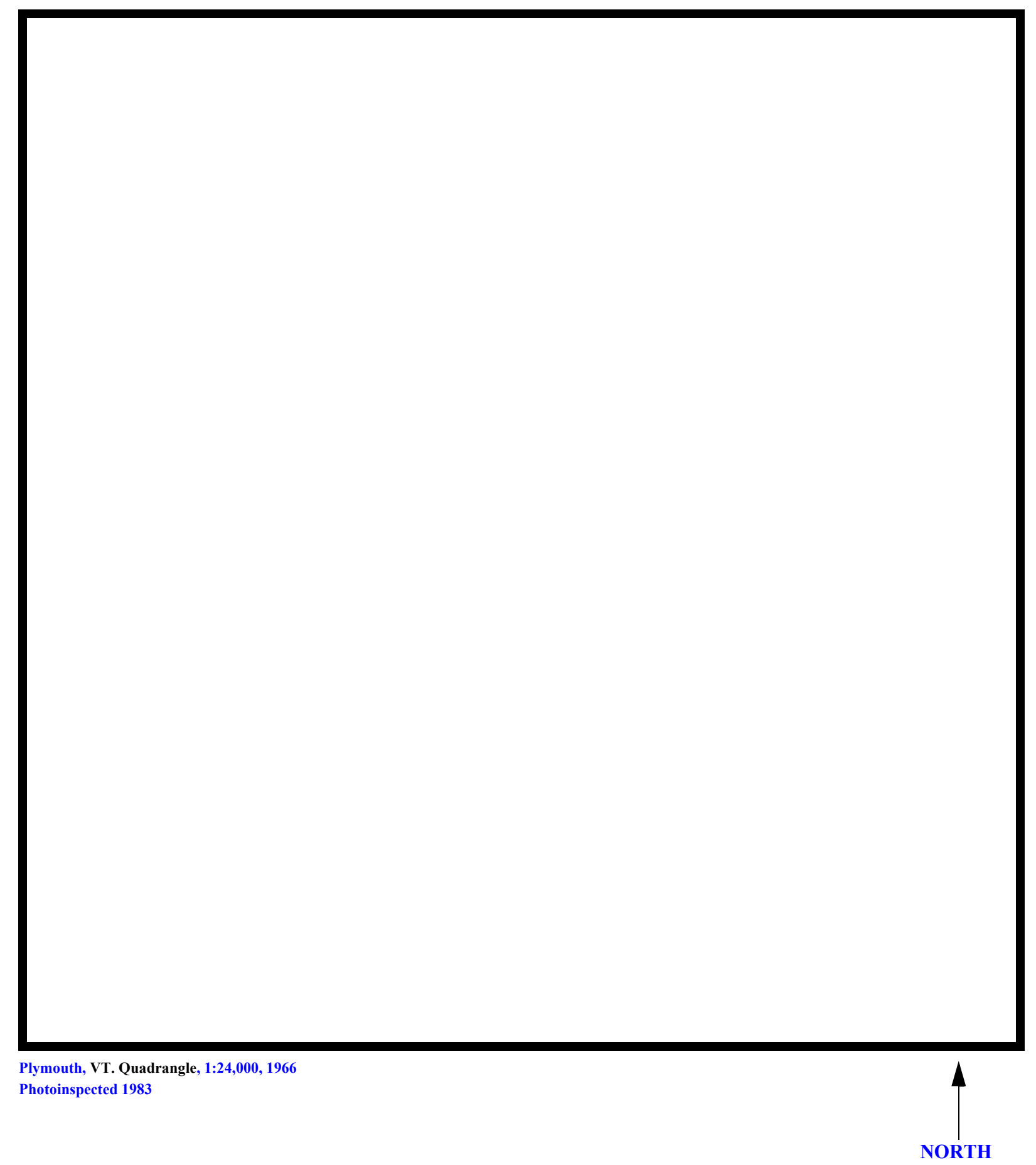

Figure 1. Location of study area on USGS 1:24,000 scale map. 
Figure 2. Location of study area on Vermont Agency of Transportation town highway map. 

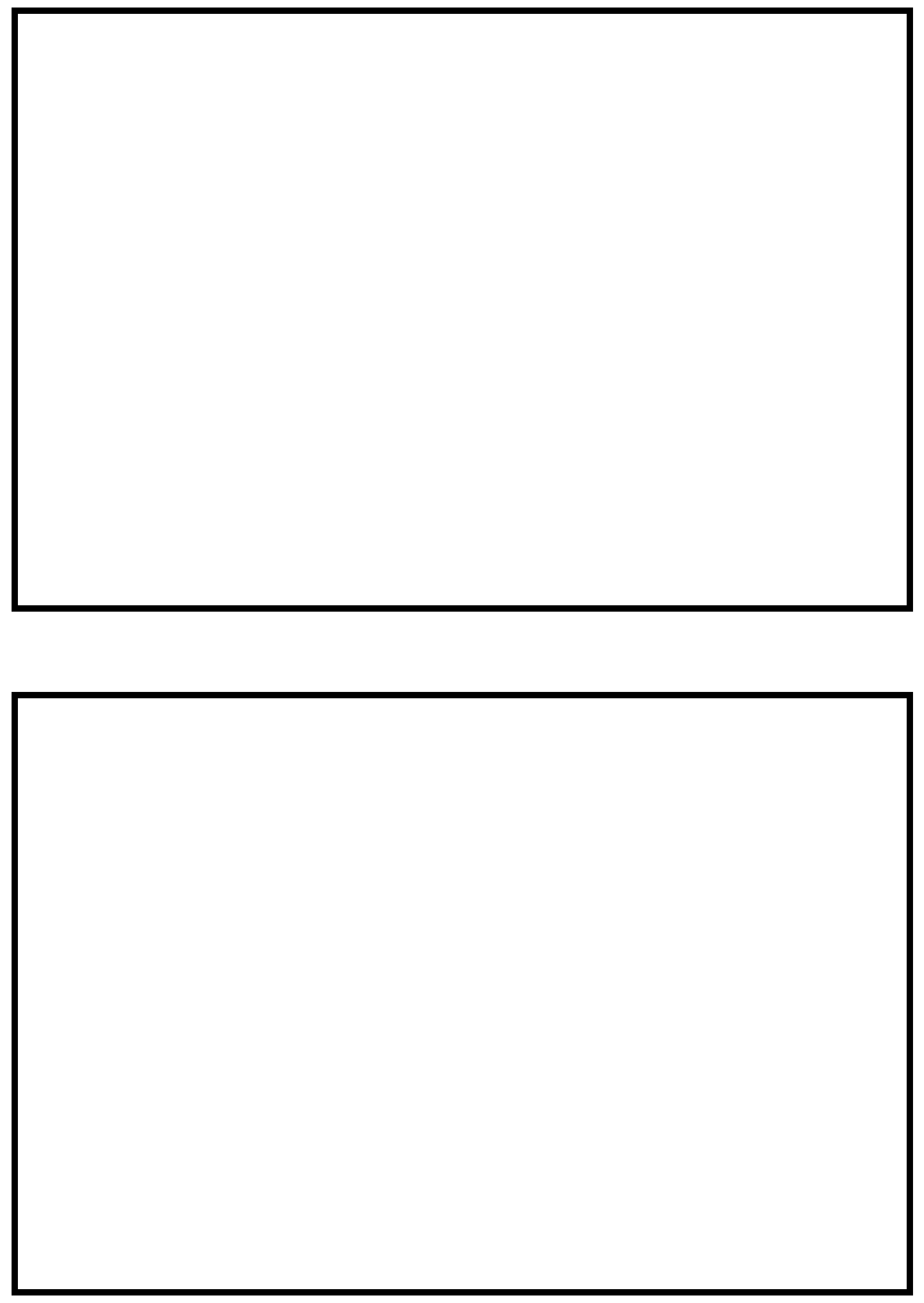

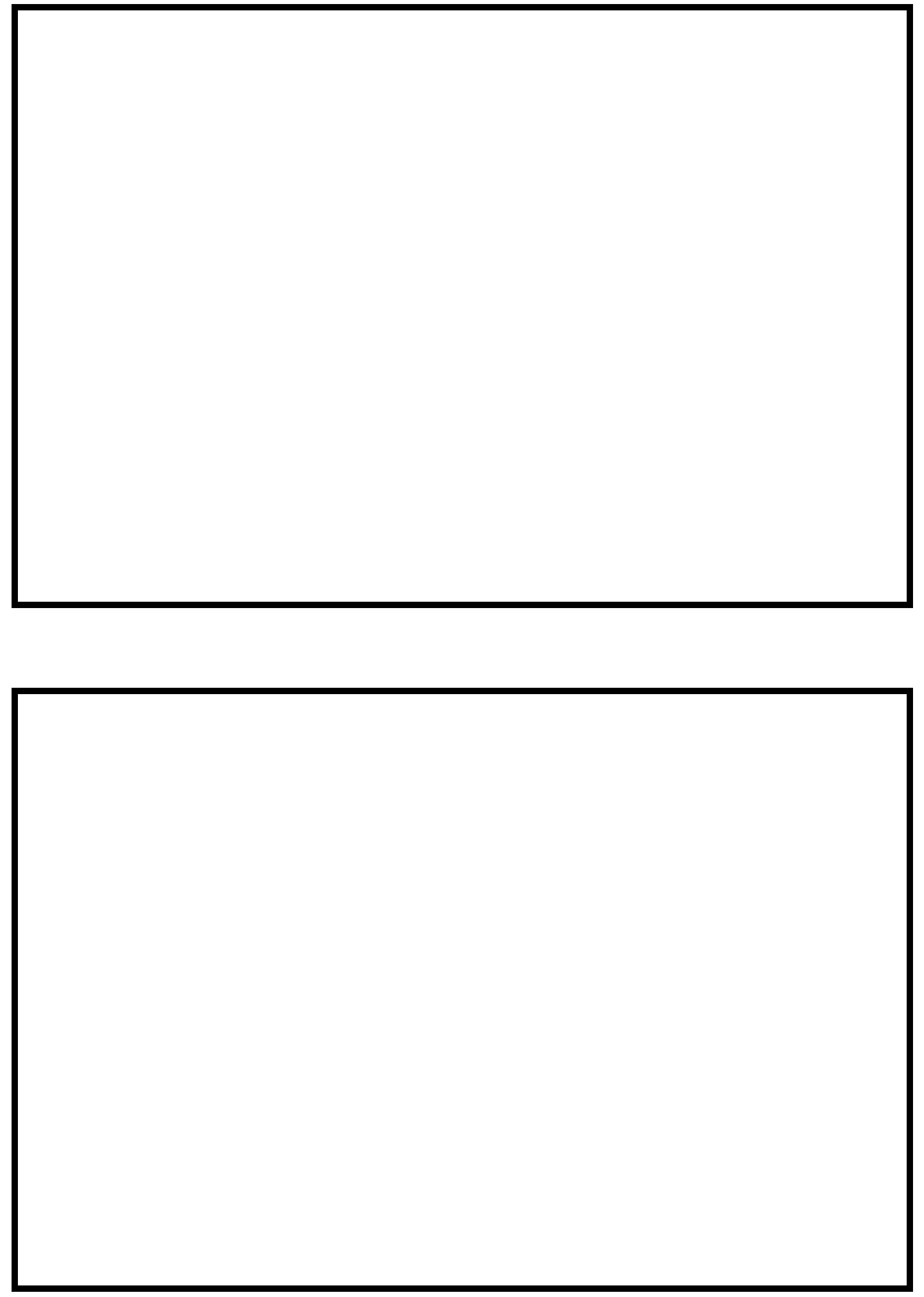


\section{LEVEL II SUMMARY}

\begin{tabular}{llllll} 
& Structure Number & RICHVT01050036 & Stream & \multicolumn{2}{c}{ Stanhope Brook } \\
& Road & VT 105 & District & 8 \\
County & Franklin & Roal &
\end{tabular}

\section{Description of Bridge}

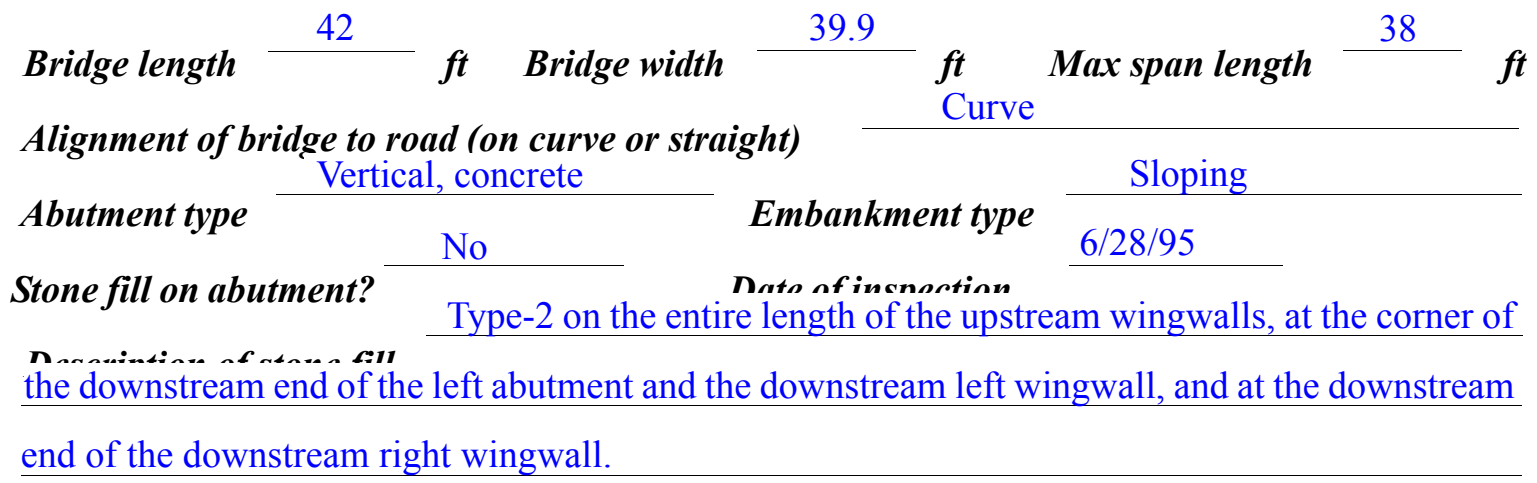

Abutments and wingwalls are concrete. There is a one

half foot deep scour hole along the downstream end of the right abutment.

\section{$\mathrm{Y} \quad \underline{15}$}

Is bridge skewed to flood flow according to $\mathrm{Y} \quad$ r survey? Angle

There is a mild channel bend through the bridge. A sçour hole has developed in the location where the bend impacts the downstream end of the right abutment.

Debris accumulation on bridge at time of Level I or Level II site visit:

Date of insnortion $6 / 28 / 95$

Level I

$6 / 28 / 95$

\section{Percent of rhannol blocked nortzontatly}

0

\section{Percent of an n....el blocked verticatty}

0

Level II

High. There was a landslide noted on the left bank upstream, which is likely to contribute debris during flood events.

Potential for debris

Field notes taken on 6/28/95.indicate there is a pile of boulders at the upstream end of Doscriho anv fonturos noar ar at tho hridoo that mav affort flou, (includo ohsorvation dato) the right abutment, which may contribute to eddy development immediately

downstream of the pile where the remnant scour is evident. 


\section{Description of the Geomorphic Setting}

General topography The channel is located in a moderate relief valley setting with flat to slightly irregular flood plains and steep valley walls on both sides.

Geomorphic conditions at bridge site: downstream (DS), upstream (US)

Date of inspection $\quad 6 / 28 / 95$

DS left: $\quad$ Steep channel bank to a narrow flood plain and VT 105 road embankment.

DS right: $\quad$ Steep channel bank to flood plain and VT 105 road embankment.

US left: $\quad$ Moderately sloping channel bank to valley wall.

US right: $\quad$ Moderately sloping channel bank to flood plain.

\section{Description of the Channel}

\begin{tabular}{|c|c|c|c|c|}
\hline \multirow[b]{2}{*}{ Average top width } & 47 & \multirow[b]{2}{*}{ Average depth } & 5 & \multirow[b]{2}{*}{$f+$} \\
\hline & $\begin{array}{c}\boldsymbol{f t} \\
\text { Cobbles } \\
\end{array}$ & & Cobbles & \\
\hline \multicolumn{2}{|c|}{ Predominant bed material } & Bank material & Perennial anc & sinuous \\
\hline with semi-allúvial ch & boundaries. $\cdots$ & 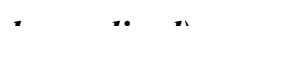 & & \\
\hline
\end{tabular}

Vegetative co ${ }^{\text {Trees with pasture on the flood plain. }} \quad \ldots \quad$.

DS left: $\quad$ Trees with a grass lawn and a house on the flood plain.

DS right: $\quad$ Brush and trees.

US left: $\quad$ A few trees with a lawn and a house on the flood plain.

US right: $\quad \underline{\mathrm{N}}$

Do banks appear stable? On 6/28/95 there was a lands lide feature noted on the unstream left date oj observation.

The assessment of

6/28/95 noted flow is influenced by a pile of boulders at the upstream end of the right abutment. Describe any obstructions in channel and date of observation. 


\title{
Hydrology
}

Drainage area $\frac{7.03}{\boldsymbol{m i}^{2}}$

Percentage of drainage area in physiographic provinces: (approximate)

Physiographic province/section

New England / Green Mountain
Percent of drainage area 100

\begin{abstract}
Is drainage area considered rural or urban?
Rural urbanization:

Describe any significant
\end{abstract}

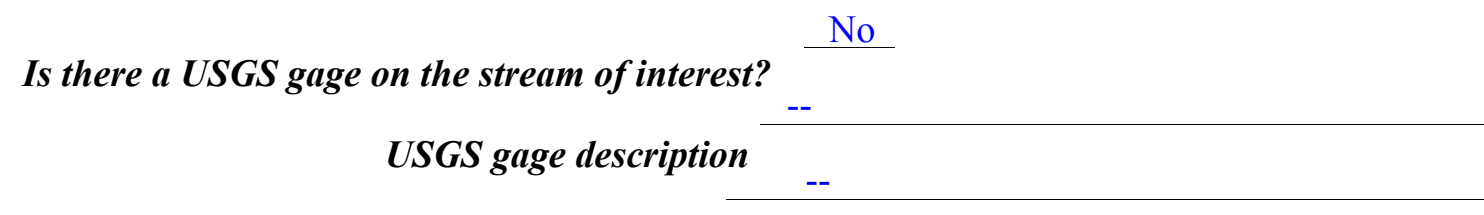

USGS gage number

Gage drainage area $\mathrm{mi}^{2}$

No

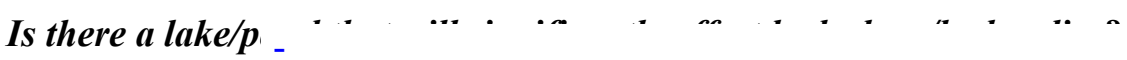

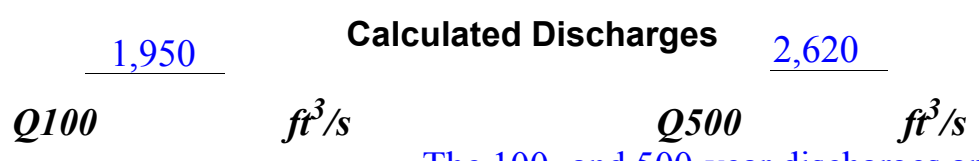

The 100- and 500-year discharges are based on

discharge frequency curves computed by use of several empirical equations (Benson, 1962;

FHWA, 1983; Johnson and Laraway, unpublished draft, 1972; Johnson and Tasker, 1974; Potter, 1957; Talbot, 1887) and those published in the flood insurance study for the town of Richford at the mouth of Stanhope Brook (FEMA, 1980). Due to the central tendency of the curve from the flood insurance study values to the others, the 100- and 500-year discharges from the flood insurance study were selected for this analysis. 


\section{Description of the Water-Surface Profile Model (WSPRO) Analysis}

Datum for WSPRO analysis (USGS survey, sea level, VTAOT plans)

VTAOT plans

Datum tie between USGS survey and VTAOT plans

The average accuracy of the

datum tie is approximately 0.6 feet.

Description of reference marks used to determine USGS datum. $\quad$ RM1 is a National

Geodetic Survey brass tablet marked "Y49, 1978" on top of the concrete right abutment, downstream end (elev. 142.74 feet, VTAOT plans' datum). RM2 is the center point of a chiseled

"X" at the upstream end of the left abutment (elev. $144.85 \mathrm{ft}$, VTAOT plans' datum).

\section{Cross-Sections Used in WSPRO Analysis}

\begin{tabular}{cccl}
\hline${ }^{1}$ Cross-section & $\begin{array}{c}\text { Section } \\
\text { Reference } \\
\text { Distance } \\
\text { (SRD) in feet }\end{array}$ & $\begin{array}{c}{ }^{2} \text { Cross-section } \\
\text { development }\end{array}$ & \multicolumn{1}{c}{ Comments } \\
\hline EXITX & -37 & 1 & $\begin{array}{l}\text { Exit section } \\
\text { Downstream Full-valley } \\
\text { section (Templated from } \\
\text { EXITX) }\end{array}$ \\
BRIDG & 0 & 2 & $\begin{array}{l}\text { Bridge section } \\
\text { RDWAY }\end{array}$ \\
APPRO & 0 & 1 & $\begin{array}{l}\text { Road Grade section } \\
\text { Modelled Approach sec- } \\
\text { tion (Templated from } \\
\text { APTEM) } \\
\text { APTEM }\end{array}$ \\
\hline & 82 & 1 & $\begin{array}{l}\text { Approach section as sur- } \\
\text { veyed (Used as a tem- } \\
\text { plate) }\end{array}$ \\
\hline
\end{tabular}

${ }^{1}$ For location of cross-sections see plan-view sketch included with Level I field form, Appendix E. For more detail on how cross-sections were developed see WSPRO input file. 


\section{Data and Assumptions Used in WSPRO Model}

Hydraulic analyses of the reach were done by use of the Federal Highway Administration's WSPRO step-backwater computer program (Shearman and others, 1986, and Shearman, 1990). The analyses reported herein reflect conditions existing at the site at the time of the study. Furthermore, in the development of the model it was necessary to assume no accumulation of debris or ice at the site. Results of the hydraulic model are presented in the Bridge Hydraulic Summary, Appendix B, and figure 7.

Channel roughness factors (Manning's " $n$ ") used in the hydraulic model were estimated using field inspections at each cross section following the general guidelines described by Arcement and Schneider (1989). Final adjustments to the values were made during the modelling of the reach. Channel " $n$ " values for the reach ranged from 0.050 to 0.055 , and overbank " $\mathrm{n}$ " values ranged from 0.035 to 0.070 .

The slope-conveyance method, outlined in the user's manual for WSPRO (Shearman, 1990), was used to compute a starting water surface. The slope used was $0.033 \mathrm{ft} / \mathrm{ft}$, which was estimated from the 100-year discharge water surface downstream of this site graphically displayed in the Flood Insurance Study for the town of Richford (FEMA, 1980, exhibit 1, panel 13p). However, for the 100- and 500-year discharges, WSPRO assumes critical depth at the exit section for the starting water surface. Analysis of the supercritical and subcritical profiles for the exit section at each discharge indicates that the slope used is a supercritical slope. Since the supercritical solution was close to critical depth, the starting water surface at critical depth was assumed to be a satisfactory solution.

The surveyed approach section (APTEM) was moved along the approach channel slope $(0.0397 \mathrm{ft} / \mathrm{ft})$ to establish the modelled approach section (APPRO), one bridge length upstream

of the upstream face as recommended by Shearman and others (1986). This method also provides a consistent approach for determining scour variables. 


\section{Bridge Hydraulics Summary}

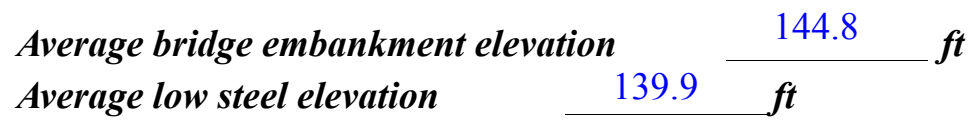

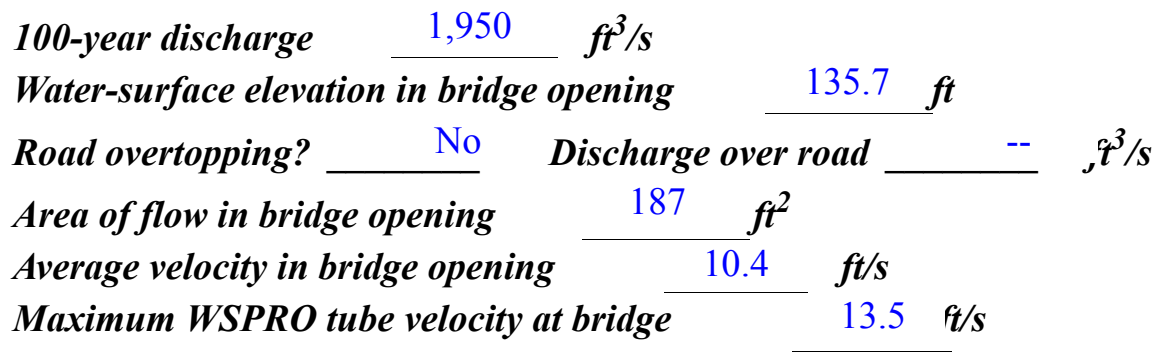

Water-surface elevation at Approach section with bridge 137.5 Water-surface elevation at Approach section without bridge Amount of backwater caused by bridge

$0.1 \quad$ it

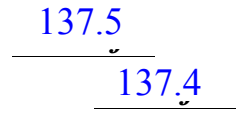

500-year discharge $\quad 2,620 \quad \mathrm{ft}^{3} / \mathrm{s}$

Water-surface elevation in bridge opening $136.0 f t$

Road overtopping? ___ No Discharge over road $-3 / s$

Area of flow in bridge opening 199

Average velocity in bridge opening $f t^{2}$

Maximum WSPRO tube velocity at bridge $13.2 \mathrm{ft} / \mathrm{s}$

$16.9, s$

Water-surface elevation at Approach section with bridge Water-surface elevation at Approach section without bridge Amount of backwater caused by bridge

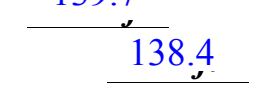

Incipient overtopping discharge ___ -- $\mathrm{ft}^{3} / \mathrm{s}$

Water-surface elevation in bridge opening $\quad--t_{t}$

Area of flow in bridge opening $-\boldsymbol{f t}^{2}$ Average velocity in bridge opening $\quad--\quad f t / s$ Maximum WSPRO tube velocity at bridge _-- $f t / s$

Water-surface elevation at Approach section with bridge Water-surface elevation at Approach section without bridge

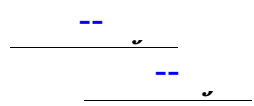
Amount of backwater caused by bridge $-{ }_{-} \boldsymbol{t}$ 


\section{Scour Analysis Summary}

\section{Special Conditions or Assumptions Made in Scour Analysis}

Scour depths were computed using the general guidelines described in Hydraulic Engineering Circular 18 (Richardson and others, 1995). Scour depths were calculated assuming an infinite depth of erosive material and a homogeneous particle-size distribution. The results of the scour analysis are presented in tables 1 and 2 and a graph of the scour depths is presented in figure 8.

Contraction scour was computed by use of the clear-water contraction scour equation (Richardson and others, 1995, p. 32, equation 20). Laursen's live-bed scour equation (Richardson and others, 1995, p. 30, equation 17) was also computed for the 100 -year modelled discharge and can be found in appendix F. For contraction scour computations, the average depth in the contracted section (AREA/TOPWIDTH) is subtracted from the depth of flow computed by the scour equation (Y2) to determine the actual amount of scour.

Abutment scour was computed by use of the Froehlich equation (Richardson and others, 1995, p. 48, equation 28). Variables for the Froehlich equation include the Froude number of the flow approaching the embankments, the length of the embankment blocking flow, and the depth of flow approaching the embankment less any roadway overtopping. 


\section{Scour Results}

100-yr discharge 500-yr discharge

Contraction scour:

(Scour depths in feet)

Main channel

Live-bed scour

Clear-water scour

Depth to armoring

Left overbank

Right overbank

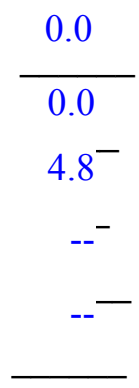

Local scour:

Abutment scour

Left abutment

6.6

8.8

$6.7-$

9.4-

Right abutment

Pier scour

Pier 1

Pier 2

Pier 3

Abutments:

Left abutment

Right abutment

Piers:

Pier 1

Pier 2

\section{Riprap Sizing}

overtopping discharge

Incipient 


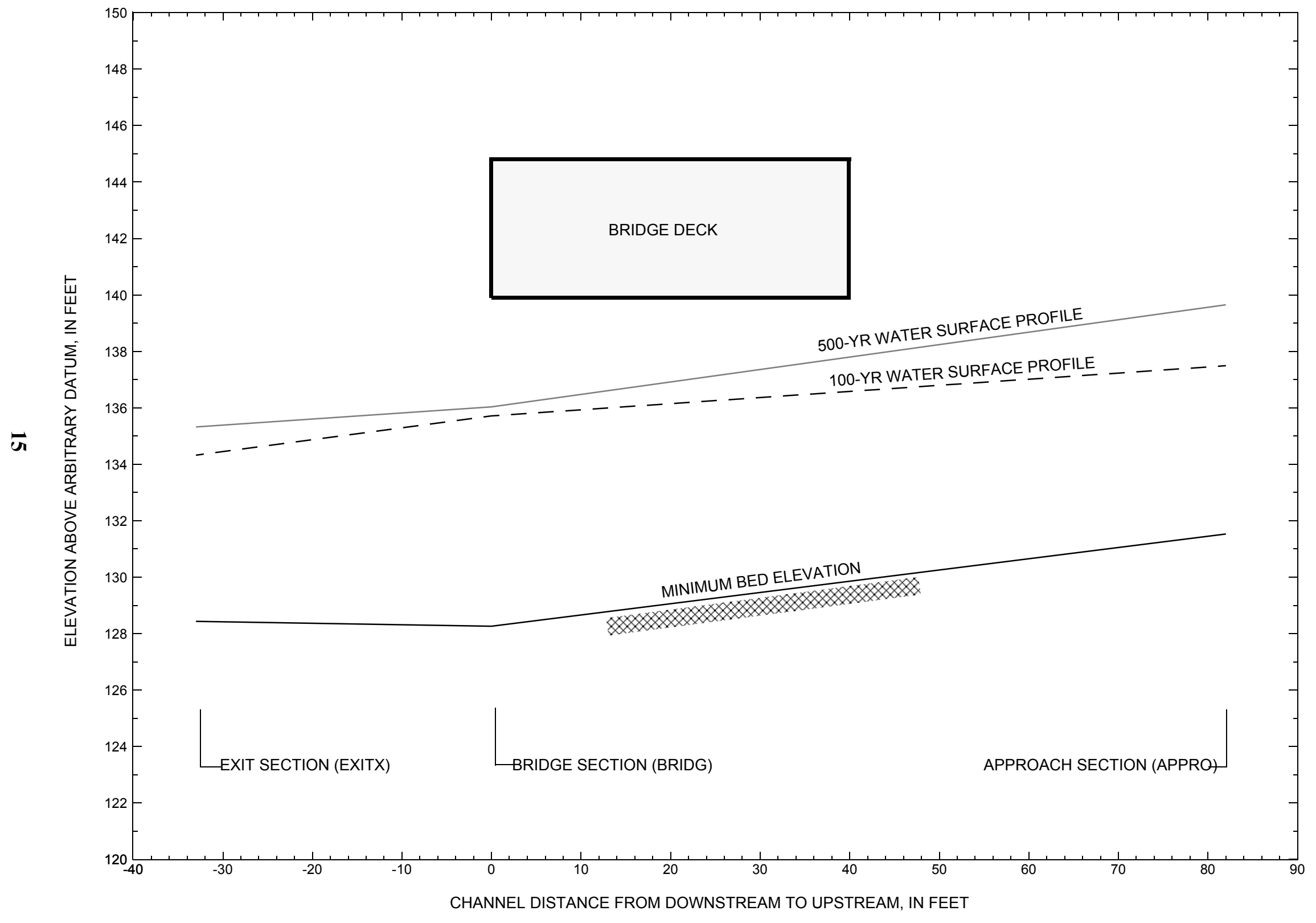

Figure 7. Water-surface profiles for the 100- and 500-yr discharges at structure RICHVT01050036 on State Route 105, crossing Stanhope Brook, Richford, Vermont. 


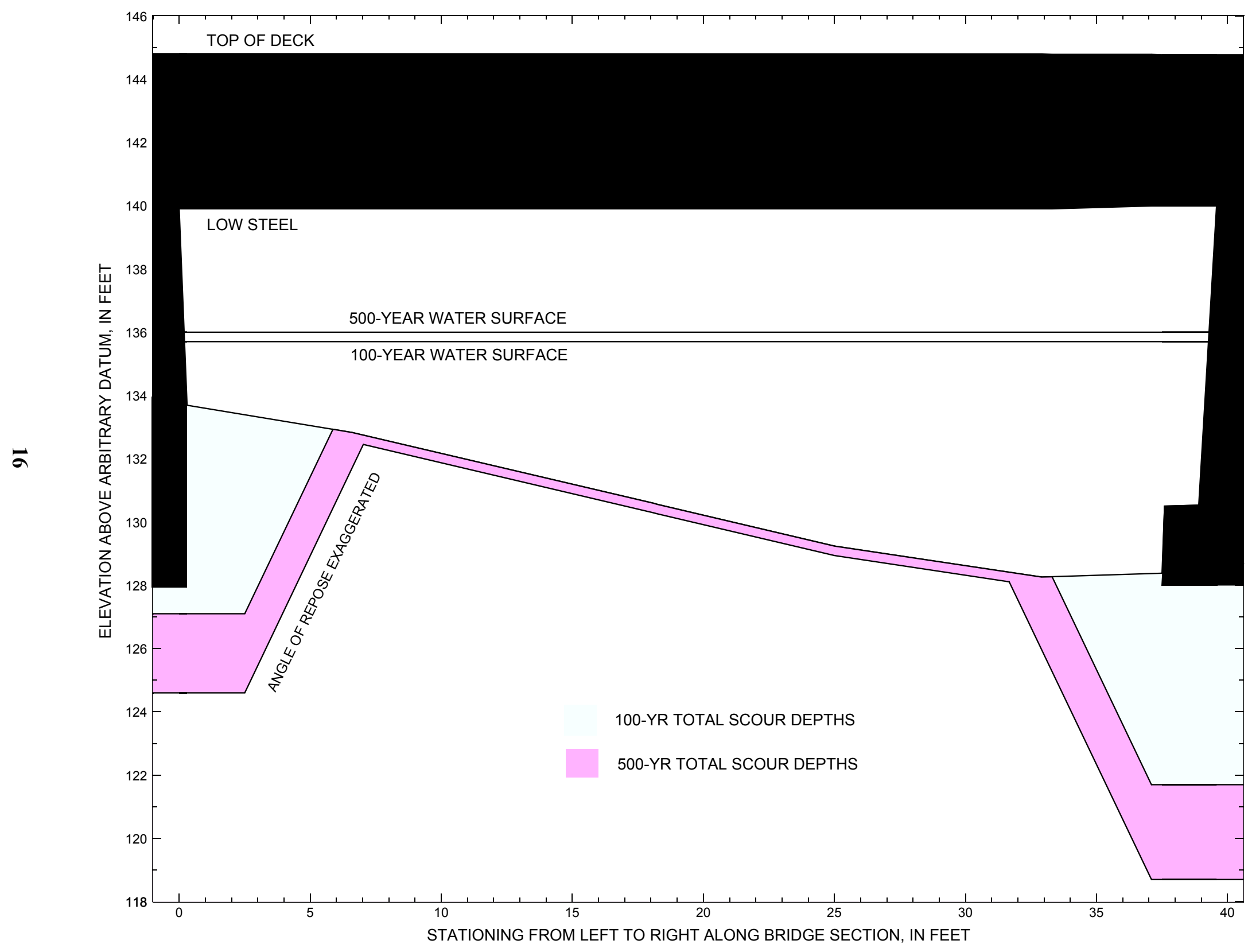

Figure 8. Scour elevations for the 100-yr and 500-yr discharges at structure RICHVT01050036 on State Route 105, crossing Stanhope Brook, Richford, Vermont. 
Table 1. Remaining footing/pile depth at abutments for the 100-year discharge at structure RICHVT01050036 on State Route 105, crossing Stanhope Brook, Richford, Vermont.

[VTAOT, Vermont Agency of Transportation; --,no data]

\begin{tabular}{|c|c|c|c|c|c|c|c|c|c|c|c|}
\hline Description & Station $^{1}$ & $\begin{array}{c}\text { VTAOT } \\
\text { Bridge seat } \\
\text { elevation } \\
\text { (feet) }\end{array}$ & $\begin{array}{l}\text { Surveyed } \\
\text { minimum } \\
\text { low-chord } \\
\text { elevation } \\
\text { (feet) }\end{array}$ & $\begin{array}{c}\text { Bottom of } \\
\text { footing } \\
\text { elevation } \\
\text { (feet) }\end{array}$ & $\begin{array}{c}\text { Channel } \\
\text { elevation at } \\
\text { abutment/ } \\
\text { pier }^{2} \\
\text { (feet) }\end{array}$ & $\begin{array}{l}\text { Contraction } \\
\text { scour depth } \\
\text { (feet) }\end{array}$ & $\begin{array}{l}\text { Abutment } \\
\text { scour } \\
\text { depth } \\
\text { (feet) }\end{array}$ & $\begin{array}{l}\text { Pier } \\
\text { scour } \\
\text { depth } \\
\text { (feet) }\end{array}$ & $\begin{array}{l}\text { Depth of } \\
\text { total scour } \\
\text { (feet) }\end{array}$ & $\begin{array}{c}\text { Elevation of } \\
\text { scour }^{2} \\
\text { (feet) }\end{array}$ & $\begin{array}{c}\text { Remaining } \\
\text { footing/pile } \\
\text { depth } \\
\text { (feet) }\end{array}$ \\
\hline \multicolumn{12}{|c|}{100 -yr. discharge is 1,950 cubic-feet per second } \\
\hline Left abutment & 0.0 & 140.8 & 139.8 & 128 & 133.7 & 0.0 & 6.6 & -- & 6.6 & 127.1 & -1 \\
\hline Right abutment & 38.9 & 140.6 & 140.0 & 128 & 128.4 & 0.0 & 6.7 & -- & 6.7 & 121.7 & -6 \\
\hline
\end{tabular}

1.Measured along the face of the most constricting side of the bridge.

2.Arbitrary datum for this study.

Table 2. Remaining footing/pile depth at abutments for the 500-year discharge at structure RICHVT01050036 on State Route 105, crossing Stanhope Brook, Richford, Vermont.

[VTAOT, Vermont Agency of Transportation; --, no data]

\begin{tabular}{|c|c|c|c|c|c|c|c|c|c|c|c|}
\hline Description & Station $^{1}$ & $\begin{array}{c}\text { VTAOT } \\
\text { Bridge seat } \\
\text { elevation } \\
\text { (feet) }\end{array}$ & $\begin{array}{l}\text { Surveyed } \\
\text { minimum } \\
\text { low-chord } \\
\text { elevation }{ }^{2} \\
\text { (feet) }\end{array}$ & $\begin{array}{c}\text { Bottom of } \\
\text { footing } \\
\text { elevation } \\
\text { (feet) }\end{array}$ & $\begin{array}{c}\text { Channel } \\
\text { elevation at } \\
\text { abutment/ } \\
\text { pier }^{2} \\
\text { (feet) }\end{array}$ & $\begin{array}{l}\text { Contraction } \\
\text { scour depth } \\
\text { (feet) }\end{array}$ & $\begin{array}{l}\text { Abutment } \\
\text { scour } \\
\text { depth } \\
\text { (feet) }\end{array}$ & $\begin{array}{l}\text { Pier } \\
\text { scour } \\
\text { depth } \\
\text { (feet) }\end{array}$ & $\begin{array}{l}\text { Depth of } \\
\text { total scour } \\
\text { (feet) }\end{array}$ & $\begin{array}{c}\text { Elevation of } \\
\text { scour }^{2} \\
\text { (feet) }\end{array}$ & $\begin{array}{c}\text { Remaining } \\
\text { footing/pile } \\
\text { depth } \\
\text { (feet) }\end{array}$ \\
\hline \multicolumn{12}{|c|}{500 -yr. discharge is 2,620 cubic-feet per second } \\
\hline Left abutment & 0.0 & 140.8 & 139.8 & 128 & 133.7 & 0.3 & 8.8 & -- & 9.1 & 124.6 & -3 \\
\hline Right abutment & 38.9 & 140.6 & 140.0 & 128 & 128.4 & 0.3 & 9.4 & -- & 9.7 & 118.7 & -9 \\
\hline
\end{tabular}

1.Measured along the face of the most constricting side of the bridge.

2.Arbitrary datum for this study. 


\section{SELECTED REFERENCES}

Arcement, G.J., Jr., and Schneider, V.R., 1989, Guide for selecting Manning's roughness coefficients for natural channels and flood plains: U.S. Geological Survey Water-Supply Paper 2339, 38 p.

Barnes, H.H., Jr., 1967, Roughness characteristics of natural channels: U.S. Geological Survey Water-Supply Paper 1849,213 p.

Benson, M. A., 1962, Factors Influencing the Occurrence of Floods in a Humid Region of Diverse Terrain: U.S. Geological Survey WaterSupply Paper 1580-B, 64 p.

Brown, S.A. and Clyde, E.S., 1989, Design of riprap revetment: Federal Highway Administration Hydraulic Engineering Circular No. 11, Publication FHWA-IP-89-016, 156 p.

Federal Highway Administration, 1983, Runoff estimates for small watersheds and development of sound design: Federal Highway Administration Report FHWA-RD-77-158

Federal Emergency Management Agency, 1980, Flood Insurance Study, Town of Richford, Franklin County, Vermont: Washington, D.C., April 1980.

Froehlich, D.C., 1989, Local scour at bridge abutments in Ports, M.A., ed., Hydraulic Engineering--Proceedings of the 1989 National Conference on Hydraulic Engineering: New York, American Society of Civil Engineers, p. 13-18.

Hayes, D.C.,1993, Site selection and collection of bridge-scour data in Delaware, Maryland, and Virginia: U.S. Geological Survey WaterResources Investigation Report 93-4017, 23 p.

Interagency Advisory Committee on Water Data, 1982, Guidelines for determining flood flow frequency: U.S. Geological Survey, Bulletin 17B of the Hydrology Subcommittee, 190 p.

Johnson, C.G. and Tasker, G.D.,1974, Progress report on flood magnitude and frequency of Vermont streams: U.S. Geological Survey OpenFile Report 74-130, 37 p.

Lagasse, P.F., Schall, J.D., Johnson, F., Richardson, E.V., Chang, F., 1995, Stream Stability at Highway Structures: Federal Highway Administration Hydraulic Engineering Circular No. 20, Publication FHWA-IP-90-014, 144 p.

Laursen, E.M., 1960, Scour at bridge crossings: Journal of the Hydraulics Division, American Society of Civil Engineers, v. 86, no. HY2, p. 39-53.

Potter, W. D., 1957, Peak rates of runoff in the New England Hill and Lowland area, Bureau of Public Roads.

Richardson, E.V. and Davis, S.R., 1995, Evaluating scour at bridges: Federal Highway Administration Hydraulic Engineering Circular No. 18, Publication FHWA-IP-90-017, 204 p.

Richardson, E.V., Simons, D.B., and Julien, P.Y., 1990, Highways in the river environment: Federal Highway Administration Publication FHWA-HI-90-016.

Ritter, D.F., 1984, Process Geomorphology: W.C. Brown Co., Debuque, Iowa, 603 p.

Shearman, J.O., 1990, User's manual for WSPRO--a computer model for water surface profile computations: Federal Highway Administration Publication FHWA-IP-89-027, 187 p.

Shearman, J.O., Kirby, W.H., Schneider, V.R., and Flippo, H.N., 1986, Bridge waterways analysis model; research report: Federal Highway Administration Publication FHWA-RD-86-108, 112 p.

Talbot, A.N., 1887, The determination of water-way for bridges and culverts.

U.S. Department of Transportation, 1993, Stream stability and scour at highway bridges, Participant Workbook: Federal Highway Administration Publication FHWA HI-91-011.

U.S. Geological Survey, 1986, Jay Peak, Vermont 7.5 Minute Series quadrangle map: U.S. Geological Survey Topographic Maps, Aerial photography, 1980; Contour interval, 6 meters; Scale 1:24,000. 


\section{APPENDIX A: \\ WSPRO INPUT FILE}




\section{WSPRO INPUT FILE}

GR

GR

GR

GR

*

$\mathrm{N}$

SA

$\mathrm{XS}$

*

*

BR

GR

GR

GR

*

CD

$\mathrm{N}$

*

*

XR

GR

GR

GR

GR

GR

GR

*

AS

GT

$\mathrm{N}$

SA

BP

*

HP 1 BRIDG

HP 2 BRIDG

HP 1 APPRO

HP 2 APPRO

*

HP 1 BRIDG 136.031136 .03

HP 2 BRIDG 136.03 * * 2620

HP 1 APPRO 139.651139 .65

HP 2 APPRO 139.65 * * 2620

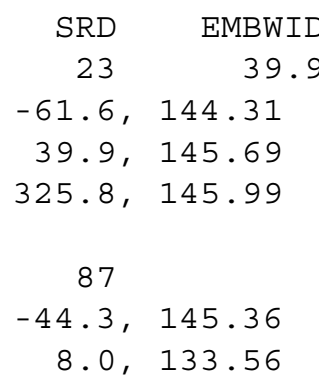

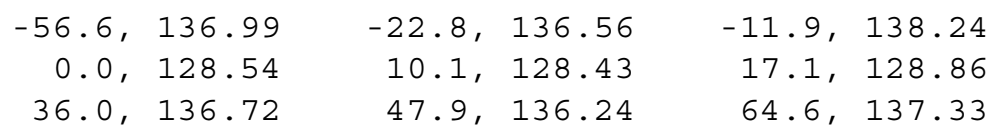

\section{*}




\section{APPENDIX B: \\ WSPRO OUTPUT FILE}


WSPRO OUTPUT FILE

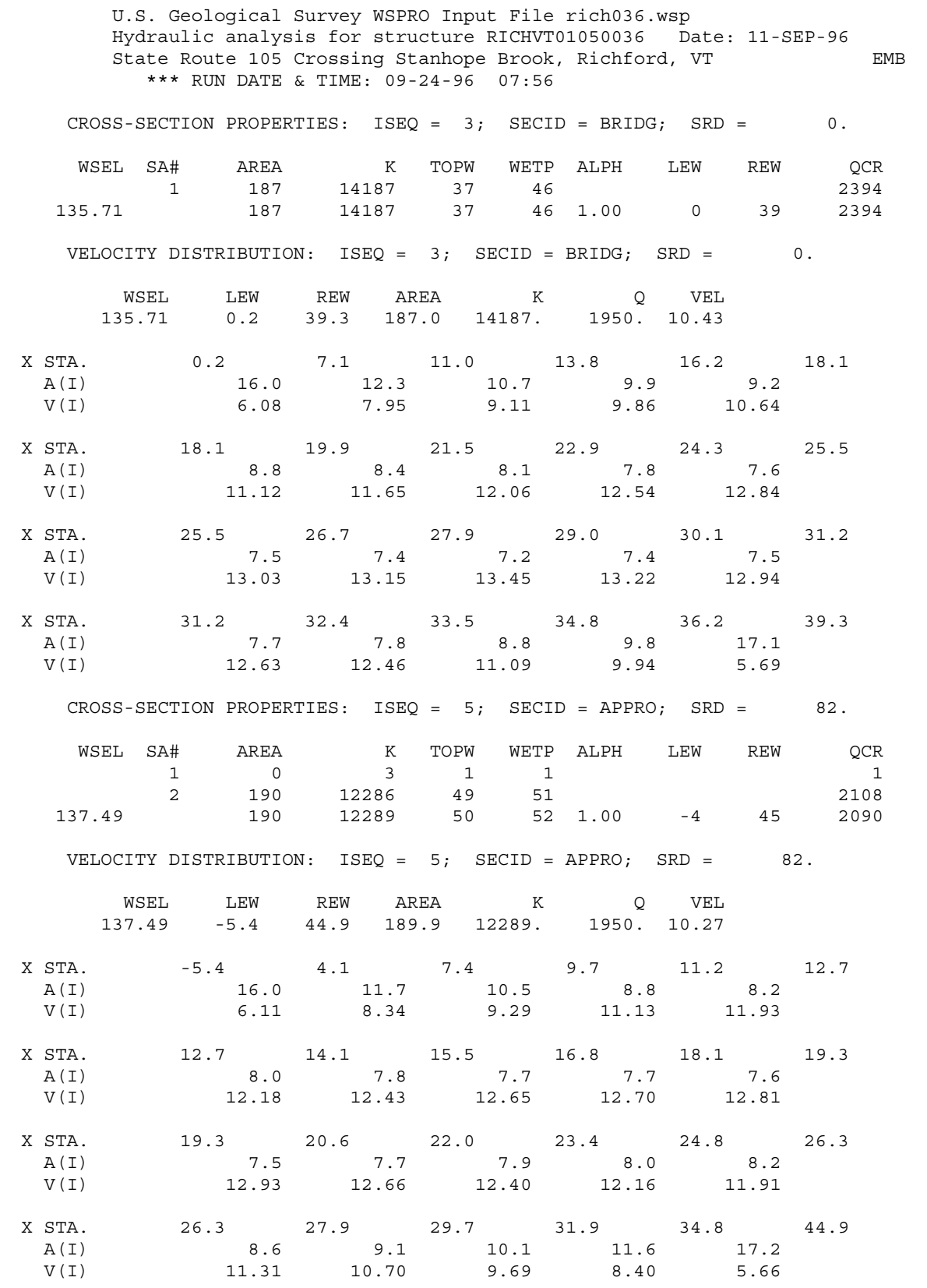


WSPRO OUTPUT FILE (continued)

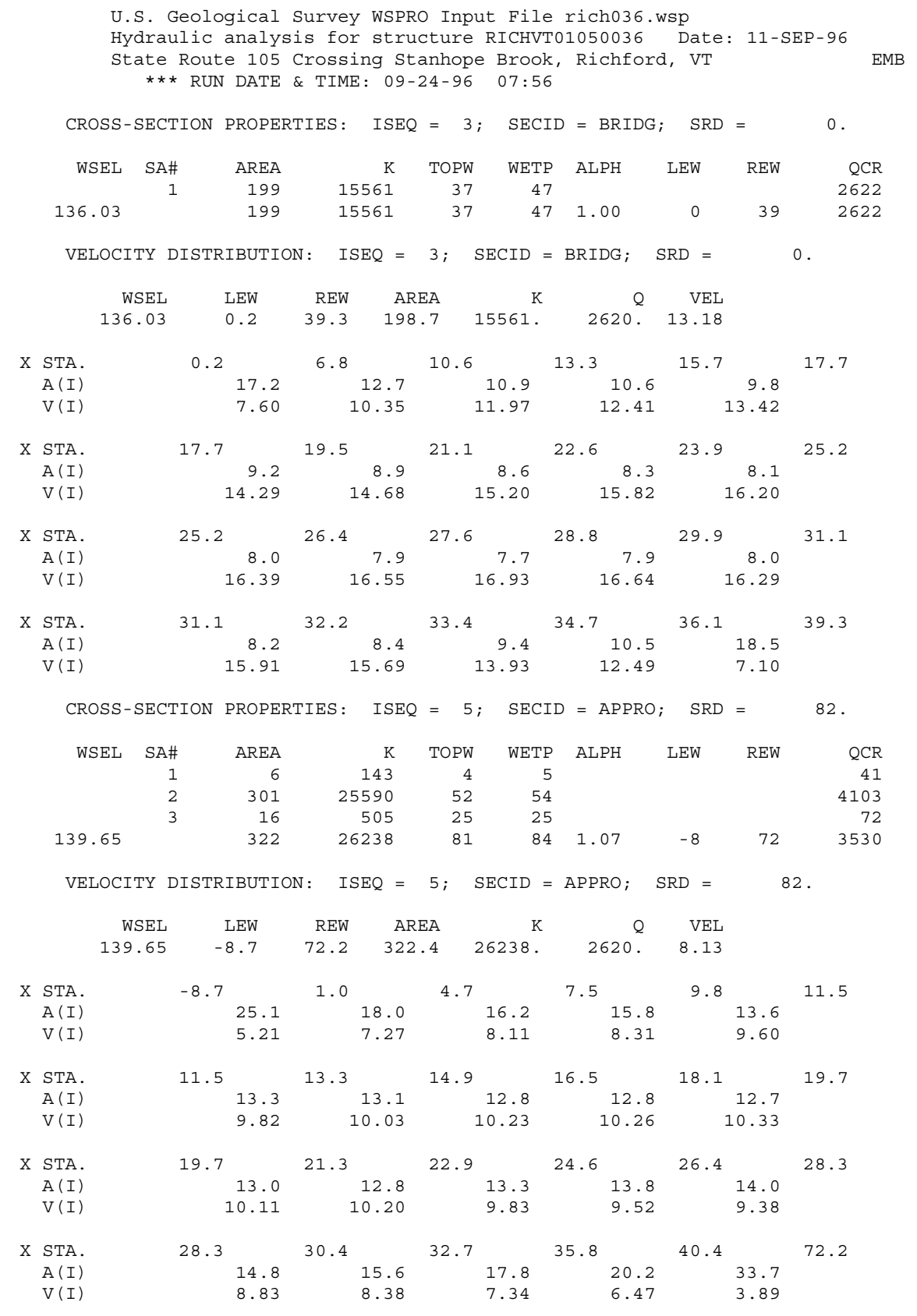


WSPRO OUTPUT FILE (continued)

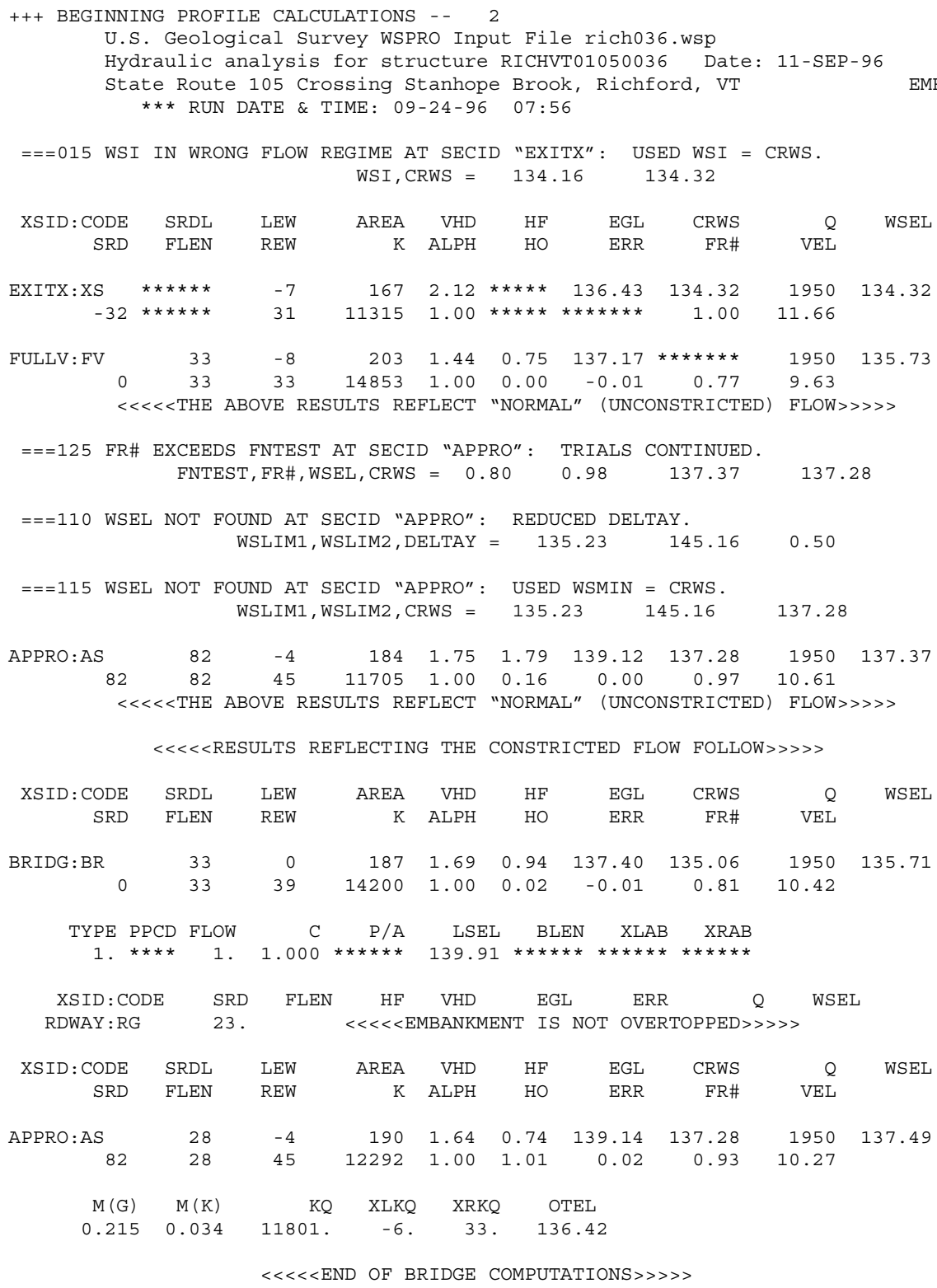

FIRST USER DEFINED TABLE.

\begin{tabular}{|c|c|c|c|c|c|c|c|c|}
\hline XSID : CODE & SRD & LEW & REW & $Q$ & $\mathrm{~K}$ & AREA & VEL & WSEL \\
\hline EXITX:XS & -33. & -8 . & 31. & 1950. & 11315. & 167. & 11.66 & 134.32 \\
\hline FULLV : FV & 0 . & -9 . & 33. & 1950. & 14853. & 203. & 9.63 & 135.73 \\
\hline BRIDG : BR & 0 . & 0 & 39. & 1950. & 14200 . & 187. & 10.42 & 135.71 \\
\hline RDWAY : RG & \multicolumn{3}{|c|}{ 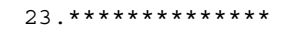 } & \multicolumn{3}{|c|}{ 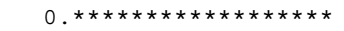 } & \multicolumn{2}{|c|}{$1.00 * * * * * * * *$} \\
\hline APPRO: AS & 82 . & -5 & 45. & 1950. & 12292 . & 190. & 10.27 & 137.49 \\
\hline XSID: CODE & XLKQ & XRKQ & & & & & & \\
\hline APPRO : AS & -6 . & 33. & 1180 & & & & & \\
\hline
\end{tabular}

SECOND USER DEFINED TABLE.

$\begin{array}{lrrrrrrrrr}\text { XSID : CODE } & \text { CRWS } & \text { FR\# } & \text { YMIN } & \text { YMAX } & \text { HF } & \text { HO } & \text { VHD } & \text { EGL } & \text { WSEL } \\ \text { EXITX:XS } & 134.32 & 1.00 & 128.43 & 141.78 * * * * * * * * * * * & 2.12 & 136.43 & 134.32 \\ \text { FULLV:FV } & * * * * * * * & 0.77 & 128.97 & 142.32 & 0.75 & 0.00 & 1.44 & 137.17 & 135.73 \\ \text { BRIDG:BR } & 135.06 & 0.81 & 128.26 & 140.00 & 0.94 & 0.02 & 1.69 & 137.40 & 135.71 \\ \text { RDWAY:RG } & * * * * * * * * * * * * * * * & 144.31 & 145.99 * * * * * * * * * * * * * * * * * * * * * * * * * * * * \\ \text { APPRO:AS } & 137.28 & 0.93 & 131.53 & 145.16 & 0.74 & 1.01 & 1.64 & 139.14 & 137.49\end{array}$


WSPRO OUTPUT FILE (continued)

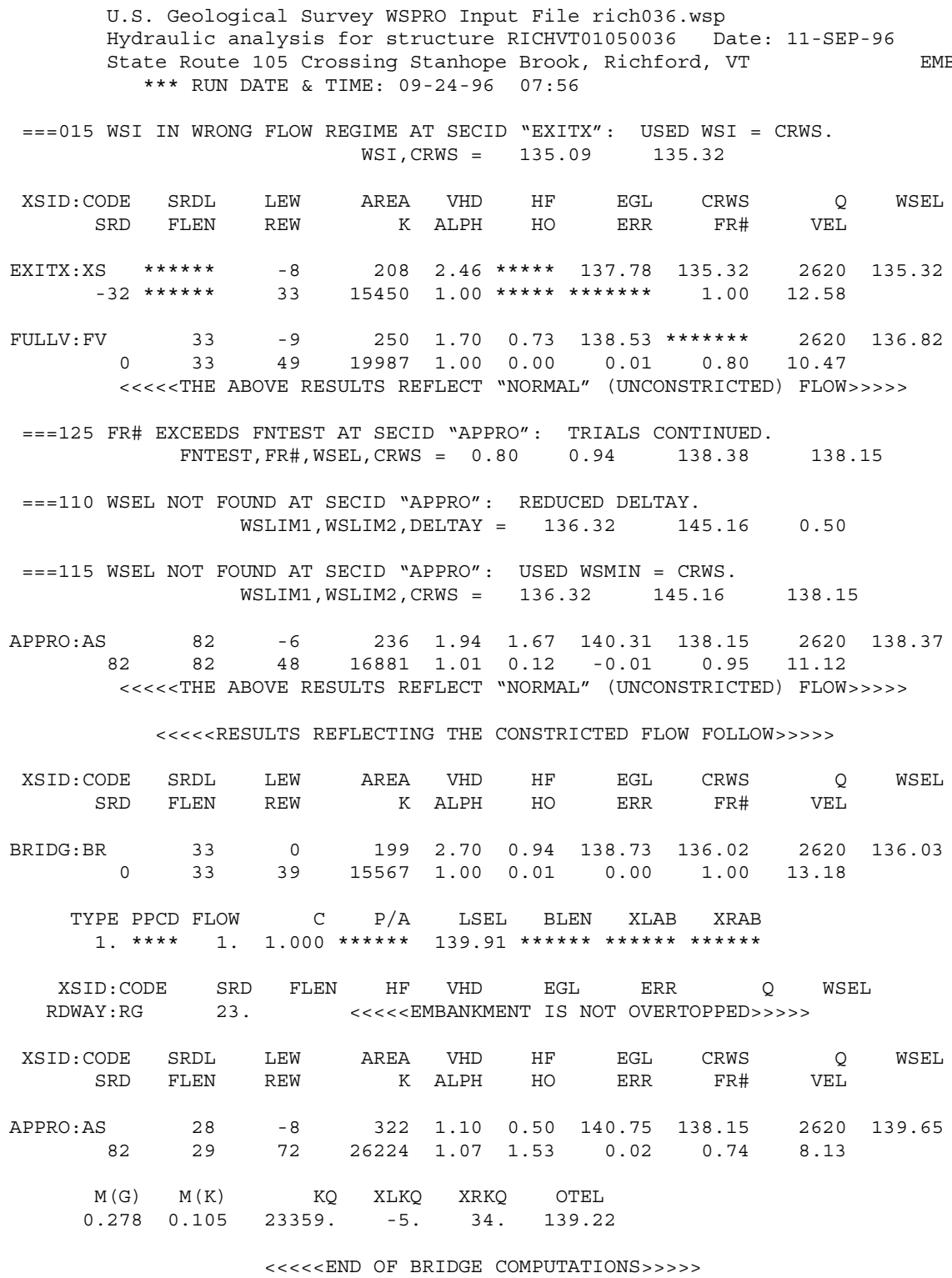

FIRST USER DEFINED TABLE.

\begin{tabular}{|c|c|c|c|c|c|c|c|c|}
\hline XSID : CODE & SRD & LEW & REW & 0 & $\mathrm{~K}$ & AREA & VEL & WSEL \\
\hline EXITX:XS & -33. & -9 . & 33. & 2620 . & 15450 . & 208. & 12.58 & 135.32 \\
\hline FULLV : FV & 0 . & -10 & 49. & 2620 . & 19987. & 250 . & 10.47 & 136.82 \\
\hline BRIDG : BR & 0 . & 0 . & 39. & 2620. & 15567. & 199. & 13.18 & 136.03 \\
\hline RDWAY : RG & \multicolumn{3}{|c|}{$23 . * * \star * * * * * * * * * * *$} & \multicolumn{3}{|c|}{ 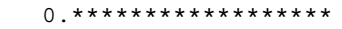 } & \multicolumn{2}{|c|}{$1.00 * * * * * * * *$} \\
\hline APPRO: AS & 82 . & -9 & 72 . & 2620 . & 26224 . & 322 . & 8.13 & 139.65 \\
\hline XSID : CODE & XLKQ & XRKQ & & & & & & \\
\hline APPRO : AS & -5 . & 34. & 2335 & & & & & \\
\hline
\end{tabular}

SECOND USER DEFINED TABLE.

$\begin{array}{lcrrrrrrrr}\text { XSID:CODE } & \text { CRWS } & \text { FR\# } & \text { YMIN } & \text { YMAX } & \text { HF } & \text { HO } & \text { VHD } & \text { EGL } & \text { WSEL } \\ \text { EXITX:XS } & 135.32 & 1.00 & 128.43 & 141.78 * * * * * * * * * * & 2.46 & 137.78 & 135.32 \\ \text { FULLV:FV } & * * * * * * * * & 0.80 & 128.97 & 142.32 & 0.73 & 0.00 & 1.70 & 138.53 & 136.82 \\ \text { BRIDG: BR } & 136.02 & 1.00 & 128.26 & 140.00 & 0.94 & 0.01 & 2.70 & 138.73 & 136.03 \\ \text { RDWAY:RG } & * * * * * * * * * * * * * * * & 144.31 & 145.99 * * * * * * * * * * * * * * * * * * * * * * * * * * * * * \\ \text { APPRO:AS } & 138.15 & 0.74 & 131.53 & 145.16 & 0.50 & 1.53 & 1.10 & 140.75 & 139.65 \\ \text { ER } & & & & & & & & & \end{array}$




\section{APPENDIX C:}

\section{BED-MATERIAL PARTICAL-SIZE DISTRIBUTION}




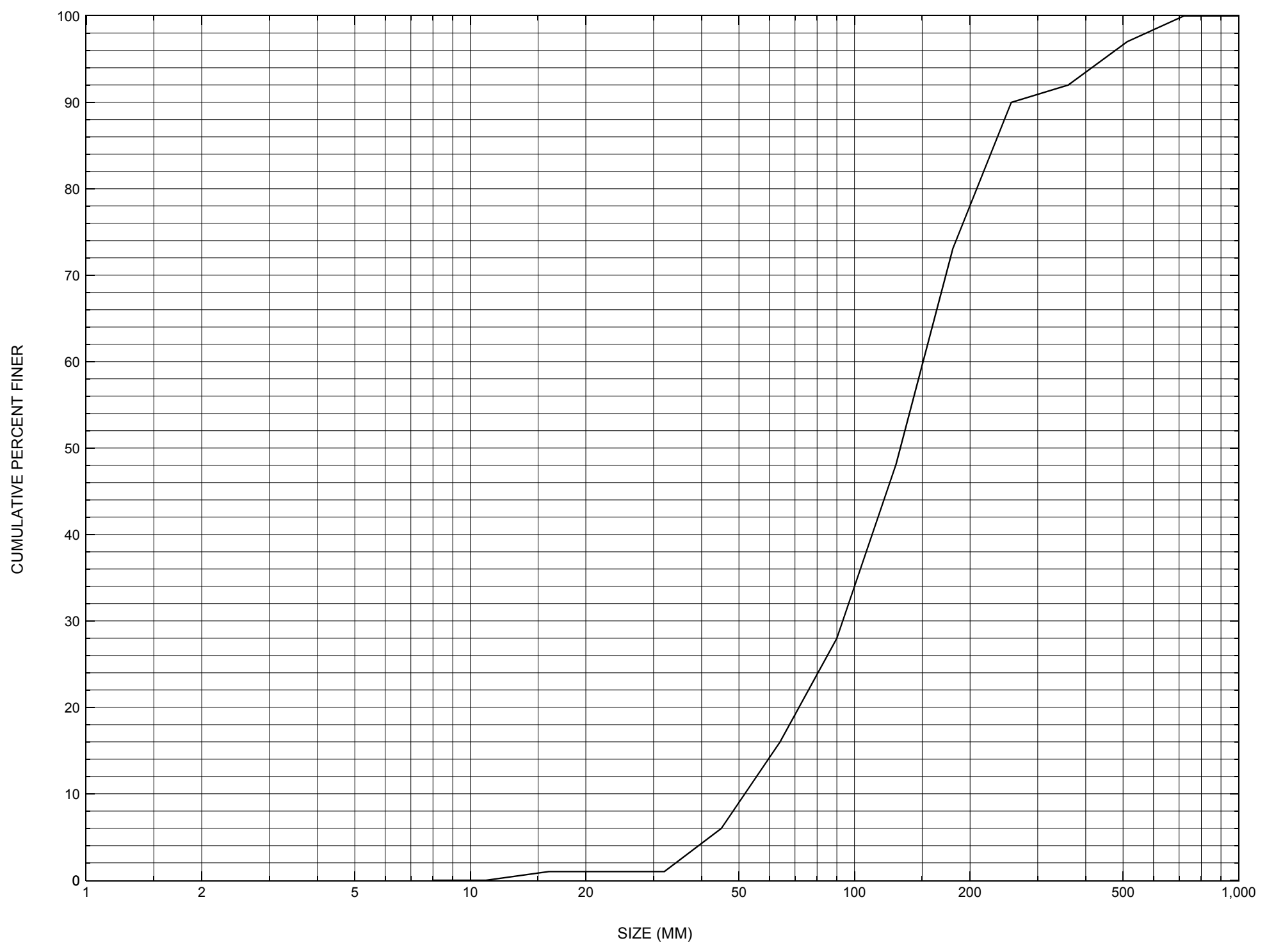

Appendix C. Bed material particle-size distribution for one pebble count transect in the channel approach of structure RICHVT01050036, in Richford, Vermont. 


\section{APPENDIX D: \\ HISTORICAL DATA FORM}




\section{Structure Number RICHVT01050036}

\section{General Location Descriptive}

Data collected by (First Initial, Full last name) $\underline{\text { L }}$. MEDALIE

Date $(M M / D D / Y Y) \_\mathbf{0 3} / \underline{\mathbf{0 8}} / \underline{95}$

Highway District Number (I - 2; nn) $\mathbf{0 8}$

Town (FIPS place code; I - 4; nnnnn) $\mathbf{5 9 1 2 5}$

Waterway (I - 6) STANHOPE BROOK

Route Number VT105

Topographic Map Jay Peak

Latitude (I - 16; nnnn.n) $\mathbf{4 4 5 9 7}$
County (FIPS county code; I - 3; nnn)

Mile marker (I - 11; nnn.nnn) $\mathbf{0 0 5 3 6 0}$

Road Name (I - 7): -

Vicinity (I - 9) 0.1 MI W JCT. VT.105A E

Hydrologic Unit Code: $\mathbf{0 2 0 1 0 0 0 7}$

Longitude (i - 17; nnnnn.n) $\mathbf{7 2 3 6 8}$

\section{Select Federal Inventory Codes}

FHWA Structure Number (I - 8) $\mathbf{2 0 0 0 3 4 0 0 3 6 0 6 1 1}$

Maintenance responsibility $(I-21 ; n n) \quad 01$

Year built (I - 27; YYYY) 1930

Average daily traffic, ADT (I - 29; nnnnnn) 001030

Year of ADT (I - 30; YY) $\mathbf{9 2}$

Opening skew to Roadway $(I-34 ; n n) \quad 22$

Operational status $(I-41 ; X)$ A

Structure type (I - 43; nnn) 104

Approach span structure type $(I-44 ; n n n) \quad \mathbf{0 0 0}$

Number of spans (I - 45; nnn) $\mathbf{0 0 1}$

Number of approach spans (I - 46; nnnn) $\mathbf{0 0 0 0}$

Comments:

The structural inspection report of 7/26/93 indicates the structure is a concrete T-beam bridge. Both concrete abutment walls have minor vertical shrinkage cracks. The left abutment has some minor scaling along flow line. The concrete wingwalls are in good condition, but with minor shrinkage cracks. The waterway has a slightly skewed alignment through structure. The streambed consists of stone and boulders. There is some scour along right abutment, with no apparent undermining. The structure is in generally good condition. There has been no apparent settlement. Very minor bank erosion is reported. Stone fill is noted along both abutment wingwalls. (Continued, page 31) 


\section{Bridge Hydrologic Data}

Is there hydrologic data available? $\underline{\mathbf{N}}$ if No, type ctrl- $n$ VTAOT Drainage area $\left(\mathrm{mi}^{2}\right)$ : -

Terrain character:

Stream character \& type: -

Streambed material: Stone and boulders

Discharge Data (cfs): $\quad Q_{2.33}$

$$
\mathrm{Q}_{50}
$$

Record flood date $(M M / D D / Y Y):-$

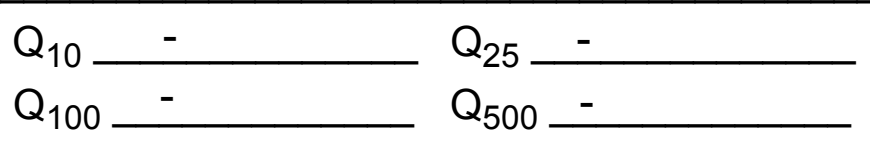

Water surface elevation $(f t):-$

Estimated Discharge (cfs): Velocity at $\mathrm{Q}-$ $(\mathrm{ft} / \mathrm{s}):$

Ice conditions (Heavy, Moderate, Light) : -

Debris (Heavy, Moderate, Light):

The stage increases to maximum highwater elevation (Rapidly, Not rapidly):

The stream response is (Flashy, Not flashy):

Describe any significant site conditions upstream or downstream that may influence the stream's stage: -

Watershed storage area (in percent): - $\%$

The watershed storage area is: - (1-mainly at the headwaters; 2- uniformly distributed; 3-immediatly upstream oi the site)

Water Surface Elevation Estimates for Existing Structure:

\begin{tabular}{|l|l|l|l|l|l|}
\hline Peak discharge frequency & $Q_{2.33}$ & $Q_{10}$ & $Q_{25}$ & $Q_{50}$ & $Q_{100}$ \\
Water surface elevation (ft)) & - & - & - & - & - \\
Velocity (ft/sec) & - & - & - & - & - \\
\hline
\end{tabular}

Long term stream bed changes: -

Is the roadway overtopped below the $\mathrm{Q}_{100}$ ? (Yes, No, Unknown): $\mathbf{U} \quad$ Frequency: -

Relief Elevation $(f t)$ :

Discharge over roadway at $Q_{100}\left(f^{3} / \mathrm{sec}\right)$ :

Are there other structures nearby? (Yes, No, Unknown): Upstream distance (miles): Town: If No or Unknown, type ctrl-n os Highway No. : Structure No. : Year Built:

Clear span (ft): Clear Height (ft): Full Waterway $\left(f t^{2}\right)$ : 
Downstream distance (miles): Town: Year Built:

Highway No. : Structure No. : Structure Type:

Clear span (ft): Clear Height $(f t)$ : Full Waterway $\left(f t^{2}\right)$ :

Comments:

Possibly up to 3 feet of channel scour has occurred along right abutment according to the report.

\section{USGS Watershed Data}

Watershed Hydrographic Data

Drainage area $(D A)$

Watershed storage (ST)

Bridge site elevation

Main channel length

499
$\mathrm{mi}^{2}$ 0 $\%$ $\%$ $10 \%$ channel length elevation $\mathbf{5 8 4}$

Main channel slope (S) 288.65 $\mathrm{ft} / \mathrm{mi}$
Lake and pond area

$\mathbf{0}$ $\mathrm{mi}^{2}$ 3438 $\mathrm{ft}$

Watershed Precipitation Data

Average site precipitation in Average headwater precipitation in

Maximum 2yr-24hr precipitation event $(124,2)$ in

Average seasonal snowfall (Sn) $\mathrm{ft}$ 


\section{Bridge Plan Data}

Are plans available? $\mathbf{Y} \quad$ If no, type ctrl-n $p / \quad$ Date issued for construction (MM/YYYY): Project Number F 034-2(1)

Minimum channel bed elevation: 131.0

Low superstructure elevation: USLAB $\underline{\mathbf{1 4 3 . 0 3}}$ DSLAB $\underline{\text { 140.82 }}$ USRAB $\underline{141.57}$ DSRAB $\underline{\mathbf{1 4 0 . 5 7}}$ Benchmark location description:

B.M. \#28, F.R.P. 20C, about 100 feet on the roadway right bankward from the right abutment and 20 feet from the roadway centerline downstream on the right overbank. The benchmark is also across VT105 from a driveway to a home, elevation 142.13

Reference Point (MSL, Arbitrary, Other): Arbitrary Datum (NAD27, NAD83, Other): Arbitrary Foundation Type: 1 (1-Spreadfooting; 2-Pile; 3- Gravity; 4-Unknown)

If 1 : Footing Thickness $\mathbf{2 . 0} \quad$ Footing bottom elevation: $\underline{\mathbf{1 2 8 . 0}}$

If 2: Pile Type: ___ (1-Wood; 2-Steel or metal; 3-Concrete) Approximate pile driven length: -

If 3: Footing bottom elevation: -

Is boring information available? $\mathbf{N}$ If no, type ctrl-n bi Number of borings taken: _-

Foundation Material Type: $\mathbf{3}$ (1-regolith, 2-bedrock, 3-unknown)

Briefly describe material at foundation bottom elevation or around piles:

NO FOUNDATION MATERIAL INFORMATION

Comments:

Notes on plans show bridge was widened later in 1960; plans for widening do not exist. Other reference points: 1) end of the downstream left wingwall where the slope of the wingwall changes from slight to nearly vertical, elevation $138.00 ; 2$ ) end of the upstream right wingwall where slope of the wingwall changes from slightly to nearly vertical, elevation $139.50 ; 3$ ) top of the upstream right wingwall at the corner where it meets the right abutment wall on the stream side, elevation 144.85. Undated page size plan in folder shows 3 timber pilings placed within left abutment, about 21 feet long, bottom elevation of both abutments are 488.5; maybe from 1960s. 


\section{Cross-sectional Data}

Is cross-sectional data available? $\mathbf{N}$ If no, type ctrl-n xs

Source (FEMA, VTAOT, Other)? -

Comments: NO CROSS SECTION INFORMATION

\begin{tabular}{|l|l|l|l|l|l|l|l|l|l|l|l|}
\hline Station & - & - & - & - & - & - & - & - & - & - & - \\
\hline Feature & - & - & - & - & - & - & - & - & - & - & - \\
\hline $\begin{array}{l}\text { Low cord } \\
\text { elevation }\end{array}$ & - & - & - & - & - & - & - & - & - & - & - \\
\hline $\begin{array}{l}\text { Bed } \\
\text { elevation }\end{array}$ & - & - & - & - & - & - & - & - & - & - & - \\
\hline $\begin{array}{l}\text { Low cord to } \\
\text { bed length }\end{array}$ & - & - & - & - & - & - & - & - & - & - & - \\
\hline Station & - & - & - & - & - & - & - & - & - & - & - \\
\hline Feature & - & - & - & - & - & - & - & - & - & - & - \\
\hline $\begin{array}{l}\text { Low cord } \\
\text { elevation }\end{array}$ & - & - & - & - & - & - & - & - & - & - & - \\
\hline $\begin{array}{l}\text { Bed } \\
\text { elevation }\end{array}$ & - & - & - & - & - & - & - & - & - & - & - \\
\hline $\begin{array}{l}\text { Low cord to } \\
\text { bed length }\end{array}$ & - & - & - & - & - & - & - & - & - & - & - \\
\hline
\end{tabular}

Source (FEMA, VTAOT, Other)?

Comments: NO CROSS SECTION INFORMATION

\begin{tabular}{|l|l|l|l|l|l|l|l|l|l|l|l|}
\hline Station & - & - & - & - & - & - & - & - & - & - & - \\
\hline Feature & - & - & - & - & - & - & - & - & - & - & - \\
\hline $\begin{array}{l}\text { Low cord } \\
\text { elevation }\end{array}$ & - & - & - & - & - & - & - & - & - & - & - \\
\hline $\begin{array}{l}\text { Bed } \\
\text { elevation }\end{array}$ & - & - & - & - & - & - & - & - & - & - & - \\
\hline $\begin{array}{l}\text { Low cord to } \\
\text { bed length }\end{array}$ & - & - & - & - & - & - & - & - & - & - & - \\
\hline Station & - & - & - & - & - & - & - & - & - & - & - \\
\hline Feature & - & - & - & - & - & - & - & - & - & - & - \\
\hline $\begin{array}{l}\text { Low cord } \\
\text { elevation }\end{array}$ & - & - & - & - & - & - & - & - & - & - & - \\
\hline $\begin{array}{l}\text { Bed } \\
\text { levation }\end{array}$ & - & - & - & - & - & - & - & - & - & - & - \\
\hline $\begin{array}{l}\text { Low cord to } \\
\text { bed length }\end{array}$ & - & - & - & - & - & - & - & - & - & - & - \\
\hline
\end{tabular}




\section{APPENDIX E: \\ LEVEL I DATA FORM}


U. S. Geological Survey

Bridge Field Data Collection and Processing Form

Qa/Qc Check by: RB Date: $\mathbf{3 / 6 / 9 6}$

\section{Structure Number}

RICHVT01050036

Computerized by: $\underline{\mathbf{R B}}$ Date: $3 / 6 / 96$

Reviewd by: Date:

\section{A. General Location Descriptive}

1. Data collected by (First Initial, Full last name) M. IVANOFF

2. Highway District Number $\mathbf{8}$

Mile marker $\mathbf{0 0 5 3 6 0}$

County FRANKLIN (011)

Town RICHFORD (59125)

Waterway (I - 6) STANHOPE BROOK

Road Name VT 105

Route Number VT 105

Hydrologic Unit Code: $\mathbf{0 2 0 1 0 0 0 7}$

3. Descriptive comments:

Located 0.1 mile west of the junction with VT 105 A East. June 1993 flash flood came up to high bank behind US right residence. Bridge project number F034-2(1), 1958.

\section{B. Bridge Deck Observations}
4. Surface cover... LBUS 6
RBUS 4
LBDS 5
RBDS 4
Overall 5

(2b us, ds,lb,rb: 1- Urban; 2- Suburban; 3- Row crops; 4- Pasture; 5- Shrub- and brushland; 6- Forest; 7- Wetland)
5. Ambient water surface... US 2
UB 2
DS $\underline{2}$
(1- pool; 2- riffle)

6. Bridge structure type 1 (1- single span; 2- multiple span; 3- single arch; 4- multiple arch; 5-cylindrical culvert; 6- box culvert; or 7- other)
7. Bridge length 42
(feet)
Span length $\underline{\mathbf{3 8}}$
(feet)
Bridge width $\underline{\mathbf{3 9 . 9}}$ (feet)

\section{Road approach to bridge:}
8. LB $\underline{2}$ RB $\underline{0}$
( 0 even, 1- lower, 2- higher)
9. $\mathrm{LB}$
RB 1
(1-Paved, 2- Not paved)

10. Embankment slope (run / rise in feet / foot):

$$
\text { US left }
$$

2.7:1

US right

2.4:1

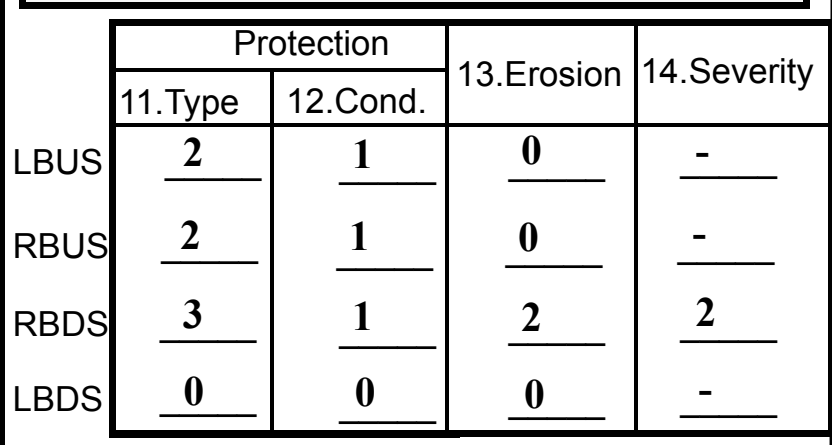

Bank protection types: 0- none; 1- < 12 inches,

2- < 36 inches; 3- < 48 inches;

4- < 60 inches; 5- wall / artificial levee

Bank protection conditions: 1- good; 2- slumped;

3- eroded; 4- failed

Erosion: 0 - none; 1- channel erosion; 2 -

road wash; 3- both; 4- other

Erosion Severity: 0 - none; 1- slight; 2- moderate; 3- severe

\section{Channel approach to bridge (BF):}

15. Angle of approach: $\mathbf{2 5}$

16. Bridge skew: 15

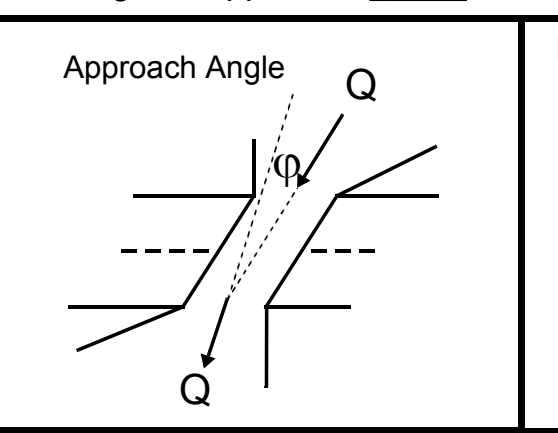

17. Channel impact zone 1 :

Where? RB (LB, RB)

Exist? $\mathbf{Y}(Y$ or $N)$ Bridge Skew Angle

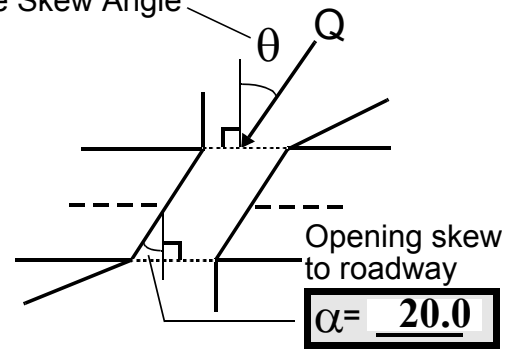

Range? 10 feet UB

Severity 1

Channel impact zone 2:

Where? $(L B, R B)$

Exist? $\mathbf{N}$

Range? - $\quad$ feet (US, UB, DS) to feet -

Impact Severity: 0- none to very slight; 1- Slight; 2- Moderate; 3- Severe 
18. Bridge Type: $4 / 1 \mathrm{a}$

1a- Vertical abutments with wingwalls

1 b- Vertical abutments without wingwalls

2- Vertical abutments and wingwalls, sloping embankment

Wingwalls perpendicular to abut. face

3- Spill through abutments

4- Sloping embankment, vertical wingwalls and abutments

1a with wingwalls

Wingwall angle less than $90^{\circ}$.

19. Bridge Deck Comments (surface cover variations, measured bridge and span lengths, bridge type variations, approach overflow width, etc.)

4. Houses are near the vicinity of the bridge except the forested US left bank.

7. Values are from the VT AOT files.

15. Angle of approach is from the center concrete pillar of the bridge rail. The US face of the bridge is curved.

\section{Upstream Channel Assessment}

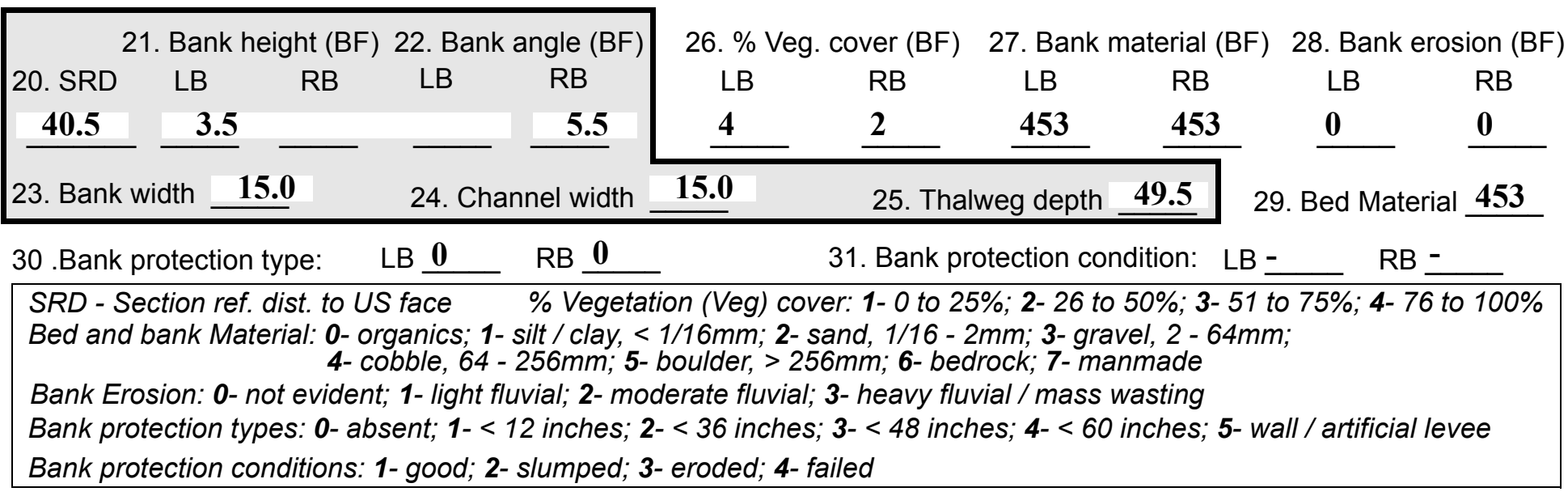

32. Comments (bank material variation, minor inflows, protection extent, etc.):

Some stone fill extends 3 feet at the US wingwall ends and 10 feet from the DS right wingwall end. 
33.Point/Side bar present? $\mathbf{N}(Y$ or $N$. if $N$ type ctrl-n pb)34. Mid-bar distance: -

35. Mid-bar width: -

36. Point bar extent: feet (US, UB) to feet (US, UB, DS) positioned $\%$ LB to $\% \mathrm{RB}$

37. Material:

38. Point or side bar comments (Circle Point or Side; Note additional bars, material variation, status, etc.):

NO POINT BARS

39. Is a cut-bank present? $\mathbf{Y}$ (Y or if $N$ type ctrl-n cb)

40. Where? $\underline{\mathbf{L B}}$ (LB or $R B)$

41. Mid-bank distance: 130

42. Cut bank extent: $\underline{\mathbf{2 0 0}}$ feet US (US, UB) to 90 feet $\underline{\mathbf{U S}}$ (US, UB, DS)

43. Bank damage: $\underline{2}$

(1- eroded and/or creep; 2- slip failure; 3- block failure)

44. Cut bank comments (eg. additional cut banks, protection condition, etc.):

On the left bank there is mass wasting with trees uprooted and 5 feet depth of slippage plane where trees are still remaining on the slope. Another cut bank is $\mathbf{3 0 0}$ feet from the bridge on the right bank.

\section{Is channel scour present? $\mathbf{N}$ ( $Y$ or if $N$ type ctrl-n cs)}

47. Scour dimensions: Length -

Width -

Depth : -

46. Mid-scour distance: -

48. Scour comments (eg. additional scour areas, local scouring process, etc.):

NO CHANNEL SCOUR

\section{Are there major confluences? $\mathbf{N}$}

51. Confluence 1: Distance Confluence 2: Distance -
52. Enters on -

Enters on -
( $Y$ or if $N$ type ctrl-n $m c)$ (LB or $R B)$ (LB or $R B)$

54. Confluence comments (eg. confluence name):

NO MAJOR CONFLUENCES. There is a dry channel entering the left bank 250 feet from the bridge. This is a meander cut off type channel for higher flows.

\section{Under Bridge Channel Assessment}

55. Channel restraint (BF)? LB 2 (1- natural bank; 2- abutment; 3- artificial levee)

\begin{tabular}{|c|c|c|c|c|c|c|c|}
\hline \multicolumn{2}{|c|}{ 56. Height (BF) } & \multicolumn{2}{|c|}{57 Angle (BF) } & \multicolumn{2}{|c|}{ 61. Material (BF) } & \multicolumn{2}{|c|}{ 62. Erosion (BF) } \\
\hline LB & RB & LB & RB & LB & RB & LB & RB \\
\hline & & & & 2 & 7 & 7 & - \\
\hline
\end{tabular}

58. Bank width (BF) 59. Channel width (Amb) 60. Thalweg depth (Amb) $\mathbf{9 0 . 0}$ 63. Bed Material -

Bed and bank Material: 0- organics; 1- silt / clay, < 1/16mm; 2- sand, 1/16 - 2mm; 3- gravel, 2 - 64mm; 4- cobble, 64 - 256mm; 5- boulder, > 256mm; 6- bedrock; 7- manmade

Bank Erosion: 0- not evident; 1- light fluvial; 2- moderate fluvial; 3- heavy fluvial / mass wasting

64. Comments (bank material variation, minor inflows, protection extent, etc.):

453 
65. Debris and Ice Is there debris accumulation?

$(Y$ or $N)$ 66. Where? $\underline{Y}$

(1- Upstream; 2- At bridge; 3- Both)

67. Debris Potential 1 ( 1- Low; 2- Moderate; 3- High)

68. Capture Efficiency 3 (1-Low; 2- Moderate; 3- High)

69. Is there evidence of ice build-up? 1 (Y or $N)$

Ice Blockage Potential $\underline{\mathbf{N}}$

(1-Low; 2- Moderate; 3- High)

70. Debris and Ice Comments:

1

Debris potential is high as further slippage of the left bank is likely. See comments for the US cut bank. Resident commented on the ice buildup as slight but it would prevent visually seeing the water surface.

\begin{tabular}{|l|c|c|c|c|c|c|c|c|}
\hline Abutments & $\begin{array}{c}\text { 71. Attack } \\
\angle \text { (BF) }\end{array}$ & $\begin{array}{c}\text { 72. Slope } \angle \\
\text { (Qmax) }\end{array}$ & $\begin{array}{c}\text { 73. Toe } \\
\text { loc. (BF) }\end{array}$ & $\begin{array}{c}\text { 74. Scour } \\
\text { Condition }\end{array}$ & $\begin{array}{c}75 . \text { Scour } \\
\text { depth }\end{array}$ & $\begin{array}{c}\text { 76. Exposure } \\
\text { depth }\end{array}$ & 77. Material & 78. Length \\
\hline LABUT & & $\mathbf{0}$ & $\mathbf{9 0}$ & $\mathbf{2}$ & $\mathbf{0}$ & $\mathbf{0}$ & $\mathbf{0}$ & $\mathbf{9 0 . 0}$ \\
\hline RABUT & $\mathbf{1}$ & $\mathbf{1 5}$ & $\mathbf{9 0}$ & & & $\mathbf{2}$ & $\mathbf{2}$ & $\mathbf{3 6 . 5}$ \\
\hline
\end{tabular}

Pushed: $L B$ or RB

Toe Location (Loc.): 0- even, 1- set back, 2- protrudes

Scour cond.: 0- not evident; 1- evident (comment); 2- footing exposed; 3-undermined footing; 4- piling exposed; 5- settled; 6- failed

Materials: 1- Concrete; 2- Stone masonry or drywall; 3- steel or metal; 4- wood

79. Abutment comments (eg. undermined penetration, unusual scour processes, debris, etc.):

0.5

2

1

75. The right abutment scour depth is about 0.5 feet with an average thalweg depth of 0.5 feet. Maximum water depth below the bridge is 1 foot.

76. The top of the right abutment footing is exposed at the DS end to the DS right wingwall.

80. Wingwalls:

Exist? Material? Scour Scour Exposure $\begin{aligned} & 81 . \\ & \text { Angle? Length? }\end{aligned}$ Condition? depth? depth?

USLWW:

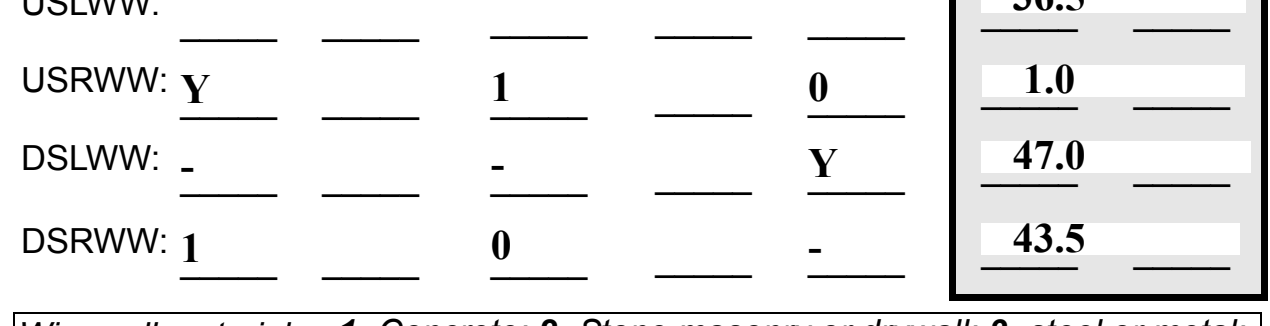

Wingwall materials: 1- Concrete; 2- Stone masonry or drywall; 3- steel or metal; 4- wood

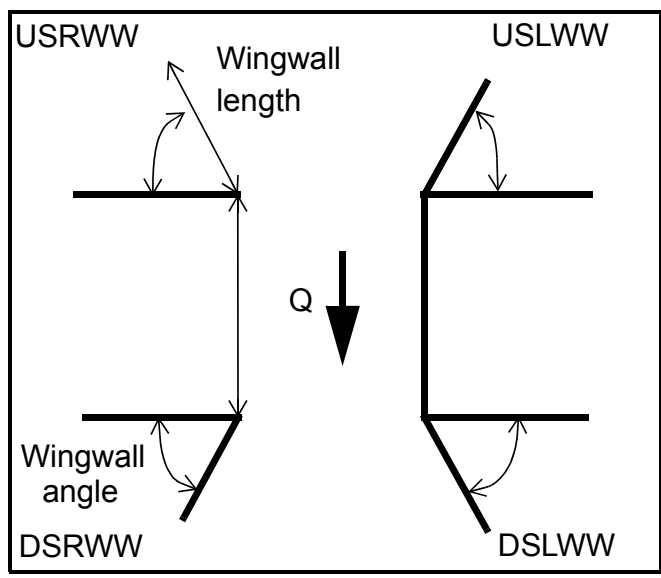

82. Bank / Bridge Protection:

\begin{tabular}{|l|l|l|l|l|l|l|l|l|}
\hline Location & USLWW & USRWW & LABUT & RABUT & LB & RB & DSLWW & DSRWW \\
\hline Type & - & $\mathbf{0}$ & $\mathbf{Y}$ & $\mathbf{0}$ & $\mathbf{1}$ & $\mathbf{1}$ & - & - \\
\hline Condition & $\mathbf{Y}$ & - & $\mathbf{1}$ & $\mathbf{2}$ & $\mathbf{1}$ & $\mathbf{1}$ & - & - \\
\hline Extent & $\mathbf{1}$ & - & $\mathbf{2}$ & $\mathbf{2}$ & $\mathbf{2}$ & $\mathbf{0}$ & $\mathbf{0}$ & - \\
\hline
\end{tabular}

Bank / Bridge protection types: 0- absent; 1- < 12 inches; 2- < 36 inches; 3- < 48 inches; 4- < 60 inches; 
83. Wingwall and protection comments (eg. undermined penetration, unusual scour processes, etc.):

-
-
-
-
-
2
1
2
2
1
3

\section{Piers:}

84. Are there piers? 80. (Y or if $N$ type ctrl-n pr)

\begin{tabular}{|l|l|l|l|l|l|l|l|}
\hline \multirow{2}{*}{$\begin{array}{l}85 . \\
\text { Pier no. }\end{array}$} & \multicolumn{3}{|c|}{ width (w) feet } & \multicolumn{3}{c|}{ elevation (e) feet } \\
\cline { 2 - 8 } & w1 & w2 & w3 & e@w1 & e@w2 & e@w3 \\
\hline Pier 1 & & & & $\mathbf{3 5 . 0}$ & $\mathbf{1 1 . 0}$ & $\mathbf{6 5 . 0}$ \\
\hline Pier 2 & & & & $\mathbf{1 2 . 5}$ & $\mathbf{6 0 . 0}$ & $\mathbf{1 0 . 5}$ \\
\hline Pier 3 & & & - & $\mathbf{3 5 . 0}$ & $\mathbf{1 8 . 0}$ & - \\
\hline Pier 4 & - & - & - & - & - & - \\
\hline
\end{tabular}

\begin{tabular}{|l|l|l|l|l|}
\hline Level 1 Pier Descr. & \multicolumn{1}{|c|}{1} & \multicolumn{1}{|c|}{2} & \multicolumn{1}{|c|}{3} & \multicolumn{1}{|c|}{4} \\
\hline 86. Location (BF) & The & at & ner & tec- \\
\hline 87. Type & top & the & with & tion \\
\hline 88. Material & of & strea & the & con- \\
\hline 89. Shape & the & m & abut & sists \\
\hline 90. Inclined? & DS & bed & ment & of a \\
\hline 91. Attack $\angle$ (BF) & right & level & - & pile \\
\hline 92. Pushed & wing & and & $\mathbf{8 2 .}$ & of \\
\hline 93. Length (feet) & - & - & - & - \\
\hline 94. \# of piles & wall & only & The & large \\
\hline 95. Cross-members & foot- & expo & right & , <48 \\
\hline 96. Scour Condition & ingis & sed & abut & in., \\
\hline 97. Scour depth & expo & at its & ment & boul- \\
\hline 98. Exposure depth & sed & cor- & pro- & ders \\
\hline
\end{tabular}

LFP, LTB, LB, MCL, MCM, MCR, RB, RTB, RFP

1- Solid pier, 2- column, 3- bent

1-Wood; 2- concrete; 3- metal; 4- stone

1- Round; 2- Square; 3- Pointed

Y-yes; $N-$ no

$L B$ or $R B$

0- none; 1- laterals; 2- diagonals; 3- both

0- not evident; 1- evident (comment);

2- footing exposed; 3- piling exposed;

4- undermined footing; 5- settled; 6- failed 
99. Pier comments (eg. undermined penetration, protection and protection extent, unusual scour processes, etc.): at the US end.

$\mathbf{N}$

100.

\section{E. Downstream Channel Assessment}

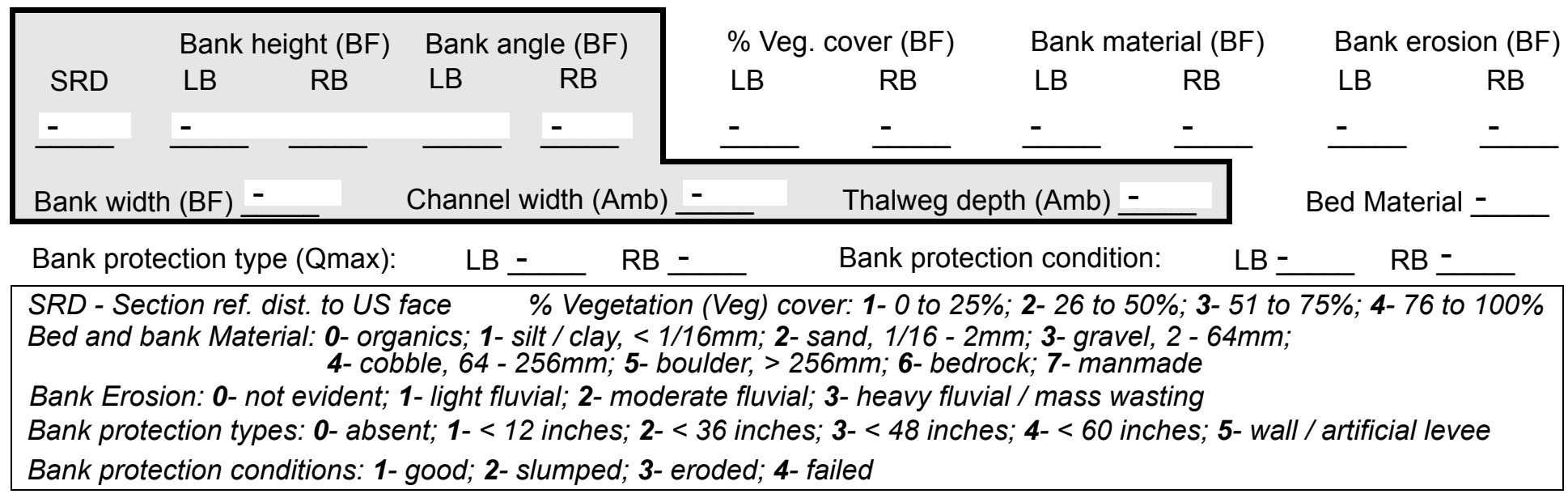

Comments (eg. bank material variation, minor inflows, protection extent, etc.):

-

-

$-$

$-$

$-$

$-$

$-$

$-$

$-$

$-$

$-$

$-$

$-$

$-$

$-$

\section{Is a drop structure present? __ ( $Y$ or $N$, if $N$ type ctrl-n $d s) \quad$ 102. Distance: ___ feet}

103. Drop: -_ feet 104. Structure material: __ (1- steel sheet pile; 2- wood pile; 3- concrete; 4- other)

105. Drop structure comments (eg. downstream scour depth):

$-$

$-$

$-$

-

$-$ 
106. Point/Side bar present? (Y or $N$. if $N$ type ctrl-n pb)Mid-bar distance:

Mid-bar width: -

Point bar extent: feet -

(US, UB, DS) to feet (US, UB, DS) positioned \%LB to $\%$ RB Material:

Point or side bar comments (Circle Point or Side; note additional bars, material variation, status, etc.):

S a cut-bank present? $\mathbf{N}$ (Y or if $N$ type ctrl-n cb) Where? $\underline{\mathbf{O}}$ (LB or RB) Mid-bank distance: PIE Cut bank extent: $\underline{\mathbf{R S}}$ feet __ (US, UB, DS) to feet __ (US, UB, DS)

Bank damage: (1- eroded and/or creep; 2- slip failure; 3- block failure)

Cut bank comments (eg. additional cut banks, protection condition, etc.):

Is channel scour present? Scour dimensions: Length 3 Width 453 Depth: 453 Scour comments (eg. additional scour areas, local scouring process, etc.): 453

0

$\mathbf{0}$

Are there major confluences? Confluence 1: Distance e fill Confluence 2: Distance 10 ( $Y$ or if $N$ type ctrl-n $m c)$ Mid-scour distance: $\underline{\mathbf{3}}$

Positioned $\underline{\mathbf{1}}$ \%LB to $\underline{\mathbf{0}}$ \%RB Confluence comments (eg. confluence name):

ond the end of the right wingwall with large boulders along both banks.

\section{F. Geomorphic Channel Assessment}

107. Stage of reach evolution Enters on exte ( $L B$ or $R B)$ How many? Ston Type nds (1- perennial; 2- ephemeral) Type bey (1- perennial; 2- ephemeral) Enters on feet ( $L B$ or $R B)$ 
108. Evolution comments (Channel evolution not considering bridge effects; See HEC-20, Figure 1 for geomorphic descriptors): 


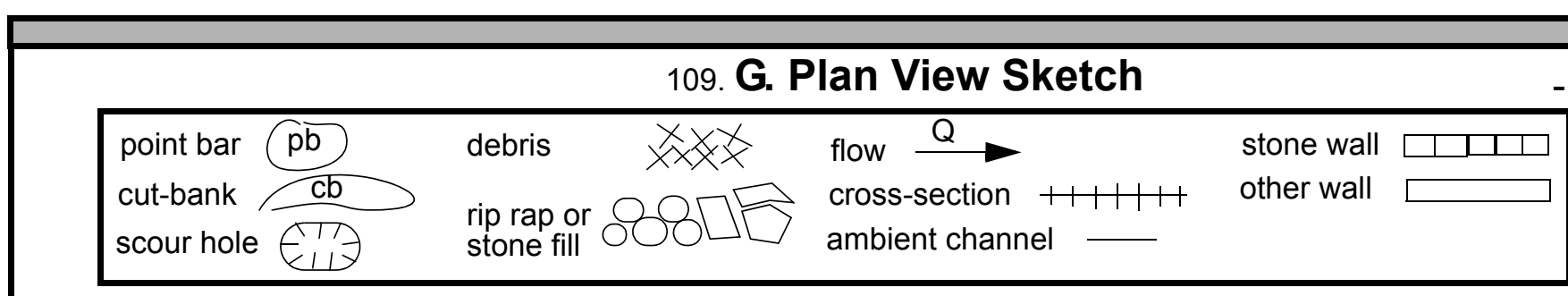


APPENDIX F:

SCOUR COMPUTATIONS 
SCOUR COMPUTATIONS

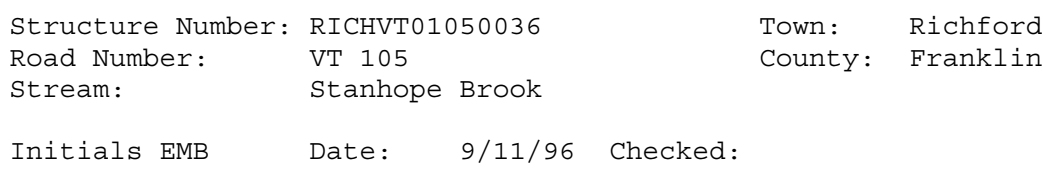

$\begin{array}{lll}3.9 & 5.8 & \text { ERR } \\ 0.0 & 1.5 & \text { ERR }\end{array}$

$\begin{array}{lll}\text { ERR } & 0.6 \quad \text { ERR }\end{array}$

$12289 \quad 26238 \quad 0$

$\begin{array}{lll}12289 & 26238 & 0 \\ 12286 & 25590 & 0\end{array}$

$3-143 \quad 0$

$3 \quad 143 \quad 0$

$0 \quad 505 \quad 0$

$0.0000 \quad 0.0000 \quad$ ERR

$1949.52555 .3 \quad$ ERR

$0.5 \quad 14.3 \quad$ ERR

$0.0 \quad 50.4 \quad$ ERR

Vm, mean velocity MC, ft/s $\quad 10.3 \quad 8.5 \quad$ ERR

$\mathrm{Vl}$, mean velocity, LOB, ft/s $\quad$ ERR $2.4 \quad$ ERR

Vr, mean velocity, ROB, ft/s ERR $3.2 \quad$ ERR

Vc-m, crit. velocity, MC, ft/s $\quad 10.6 \quad 11.4 \mathrm{~N} / \mathrm{A}$

VC-1, crit. velocity, LOB, ft/s $\quad 0.0 \quad 0.0 \quad \mathrm{~N} / \mathrm{A}$

VC-r, crit. velocity, ROB, ft/s N/A $0.0 \quad \mathrm{~N} / \mathrm{A}$

Results

Live-bed(1) or Clear-Water(0) Contraction Scour? Main Channel Left Overbank Right Overbank

$\begin{array}{lll}0 & 0 & \text { N/A } \\ \text { N/A } & 1 & \text { N/A } \\ \text { N/A } & 1 & \text { N/A }\end{array}$




\begin{tabular}{|c|c|c|c|c|c|c|}
\hline \multicolumn{7}{|c|}{$\begin{array}{l}\text { Laursen's Live Bed Contraction Scour } \\
\text { y2/y1 } 1(\mathrm{Q} 2 / \mathrm{Q} 1)^{\wedge}(6 / 7) *(\mathrm{~W} 1 / \mathrm{W} 2)^{\wedge}(\mathrm{k} 1) \\
\text { ys=y2-y_bridge } \\
\text { (Richardson and others, 1995, p. } 30, \text { eq. } 17 \text { and } 18)\end{array}$} \\
\hline & Approach & & & Bridge & & \\
\hline Characteristic & $100 \mathrm{yr}$ & $500 \mathrm{yr}$ & Other $Q$ & $100 \mathrm{yr}$ & $500 \mathrm{yr}$ & Other Q \\
\hline Q1, discharge, cfs & 1950 & 2620 & 0 & 1950 & 2620 & 0 \\
\hline Total conveyance & 12289 & 26238 & 0 & 14187 & 15561 & 0 \\
\hline Main channel conveyance & 12286 & 25590 & 0 & 14187 & 15561 & 0 \\
\hline Main channel discharge & 1950 & 2555 & ERR & 1950 & 2620 & ERR \\
\hline Area - main channel, ft2 & 190 & 301 & 0 & 187 & 198.7 & 0 \\
\hline (W1) channel width, ft & 49 & 52 & 0 & 36.7 & 36.7 & 0 \\
\hline (Wp) cumulative pier width, & 0 & 0 & 0 & 0 & 0 & 0 \\
\hline W1, adjusted bottom width(ft) & 49 & 52 & 0 & 36.7 & 36.7 & 0 \\
\hline D50, ft & 0.432 & 0.432 & 0.432 & & & \\
\hline w, fall velocity, ft/s (p. 32) & 5.37 & 5.37 & 0 & & & \\
\hline y, ave. depth flow, ft & 3.88 & 5.79 & $\mathrm{~N} / \mathrm{A}$ & 5.10 & 5.41 & ERR \\
\hline S1, slope EGL & 0.024 & 0.022 & 0 & & & \\
\hline $\mathrm{P}$, wetted perimeter, $\mathrm{MC}$, ft & 51 & 54 & 0 & & & \\
\hline R, hydraulic Radius, ft & 3.725 & 5.574 & ERR & & & \\
\hline V*, shear velocity, ft/s & 1.697 & 1.987 & $\mathrm{~N} / \mathrm{A}$ & & & \\
\hline $\mathrm{V} * / \mathrm{w}$ & 0.316 & 0.370 & $\mathrm{ERR}$ & & & \\
\hline $\begin{array}{l}\text { Bed transport coeff., } \mathrm{k} 1,(0.59 \text { if } \\
\mathrm{k} 1\end{array}$ & $\begin{array}{l}\mathrm{V} * / \mathrm{w}<0.5 \\
0.59\end{array}$ & $\begin{array}{l}0.64 \text { if } \\
0.59\end{array}$ & $\begin{array}{l}5<\mathrm{V}^{*} / \mathrm{W}<2 \\
0\end{array}$ & 0.69 if & $\mathrm{V} * / \mathrm{w}>2.0$ & p. 33$)$ \\
\hline y2, depth in contraction, ft & 4.60 & 7.26 & $\mathrm{ERR}$ & & & \\
\hline ys, scour depth, ft (y2-y_bridge) & -0.50 & $\mathrm{~N} / \mathrm{A}$ & $\mathrm{N} / \mathrm{A}$ & & & \\
\hline
\end{tabular}

Clear water Contraction Scour in MAIN CHANNEL

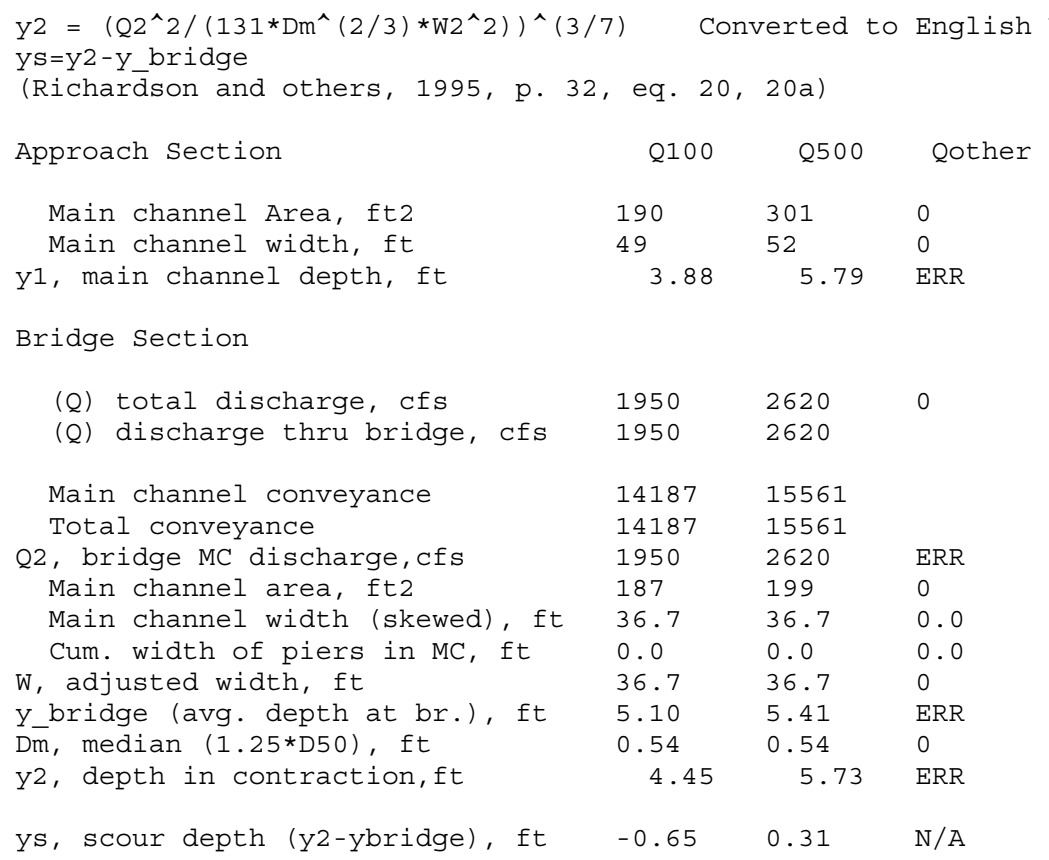

ARMORING

$\begin{array}{lllll}\text { D90 } & 0.839895 & 0.839895 & \\ \text { D95 } & 1.459 & 1.459 & \\ \text { Critical grain size,Dc, ft } & 0.5917 & 0.9199 & \text { ERR } \\ \text { Decimal-percent coarser than DC } & 0.269 & 0.095 & \\ \text { Depth to armoring,ft } & 4.82 & 26.29 & \text { ERR }\end{array}$




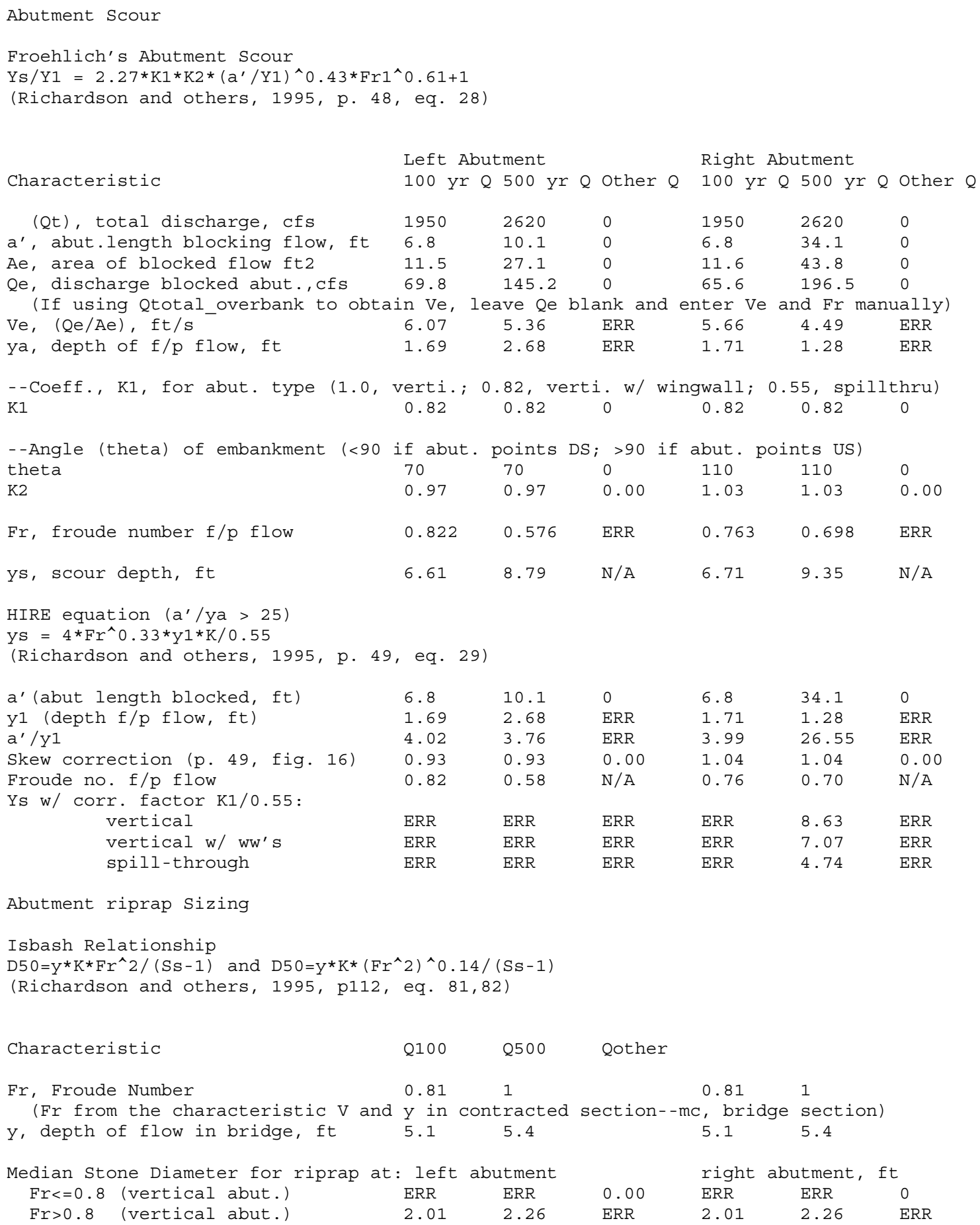

